\title{
Somatostatin system: molecular mechanisms regulating anterior pituitary hormones
}

\author{
Tamar Eigler and Anat Ben-Shlomo
}

Division of Endocrinology, Diabetes and Metabolism, Department of Medicine, Pituitary Center, Cedars Sinai Medical Center, Davis Building, Room 3066, 8700 Beverly Boulevard, Los Angeles, California 90048, USA

Correspondence should be addressed to A Ben-Shlomo Email benshlomoa@cshs.org

\begin{abstract}
The somatostatin (SRIF) system, which includes the SRIF ligand and receptors, regulates anterior pituitary gland function, mainly inhibiting hormone secretion and to some extent pituitary tumor cell growth. SRIF-14 via its cognate G-protein-coupled receptors (subtypes 1-5) activates multiple cellular signaling pathways including adenylate cyclase/cAMP, MAPK, ion channel-dependent pathways, and others. In addition, recent data have suggested SRIF-independent constitutive SRIF receptor activity responsible for GH and ACTH inhibition in vitro. This review summarizes current knowledge on ligand-dependent and independent SRIF receptor molecular and functional effects on hormone-secreting cells in the anterior pituitary gland.
\end{abstract}

\section{Introduction}

The anterior pituitary gland is subjected to the stimulatory and inhibitory effects of multiple regulators. Somatostatin (SRIF) and its cognate receptors (sst1-sst5) exhibit a dominant inhibitory role in pituitary gland regulation. Hypothalamic SRIF was isolated from the hypothalamus (Burgus et al. 1973) and subsequently demonstrated to be secreted throughout the brain and from multiple peripheral organs, affecting multiple tissues (Patel 1999).

The pituitary gland is positioned outside the bloodbrain barrier, and is composed of two entities that merge during embryonic development, the anterior and intermediate lobes that ascend from the oral ectoderm and the posterior lobe that descends from the hypothalamus (Drouin 2011). The anterior pituitary harbors hormonesecreting epithelial-origin cell types, including those expressing prolactin (PRL) and growth hormone (GH) that compose most of the gland, centrally located adrenocorticotropin (ACTH)-secreting and thyrotropin
(TSH)-secreting cells, and laterally scattered gonadotropin (follicle-stimulating hormone (FSH) and luteinizing hormone (LH)) cells. The intermediate lobe contains cells secreting $\alpha$-melanotropin; however, this lobe degenerates in humans. The posterior lobe harbors axons descending from neurons located in the hypothalamic nuclei and release vasopressin (antidiuretic hormone) and oxytocin (Bichet 2011). As various SRIF receptor expression levels and subtype profiles were observed on all pituitary cell types (Ben-Shlomo \& Melmed 2010), a range of SRIF system effects are exhibited in the different cell types.

Cortistatin (CST), a ligand with SSTR binding affinity similar to that of SRIF, is expressed in the cerebral cortex and hippocampus, but not in the hypothalamus (Spier \& de Lecea 2000); hence, it is not a major endocrine regulator of pituitary signaling and function.

SRIF receptors (SSTRs) exhibit in vitro constitutive activity, independently of SRIF or CST presence, and

Published by Bioscientifica Ltd 
regulate GH and ACTH production (Ben-Shlomo et al. 2009, 2013). The SRIF ligand and the five SRIF receptor subtypes (sst1-sst5) regulate pituitary function at two levels, via ligand exposure and potentially via selective receptors, independently of the ligand.

\section{Somatostatin}

Somatostatinergic neuronal cell bodies lie within the anterior periventricular nucleus and comprise $80 \%$ of hypothalamic SRIF immunoreactivity. The remaining hypothalamic SRIF-producing neuronal bodies lie within the paraventricular, arcuate, and ventromedial nuclei. Retrograde-tracing functional topography of hypothalamic SRIF neurons in the male rat demonstrated that SRIF neurons regulating the pituitary are confined within the periventricular and paraventricular nuclei, but not in the arcuate nucleus (Kawano \& Daikoku 1988). These neurons send axonal projections to the median eminence at the base of the hypothalamus (Fig. 1). Ultrastructural morphometric analysis of SRIF-like immunoreactive neurons indicated that more than half of all terminals in the median eminence exhibit SRIF-containing vesicles with estimated $0.7 \mathrm{mM}$ concentration per vesicle (Foster \& Johansson 1985). Hypothalamic SRIF neuron axons descend from the median eminence toward the pituitary stalk and terminate at the pituitary portal blood vessel system, releasing SRIF into the blood reaching the anterior pituitary cells (Patel 1999) or travel through the neural pituitary stalk into the posterior pituitary (Patel \& Srikant 1986; Fig. 2).

SRIF is cleaved from a common SRIF prohormone into several cyclic tetradecapeptide products by prohormone

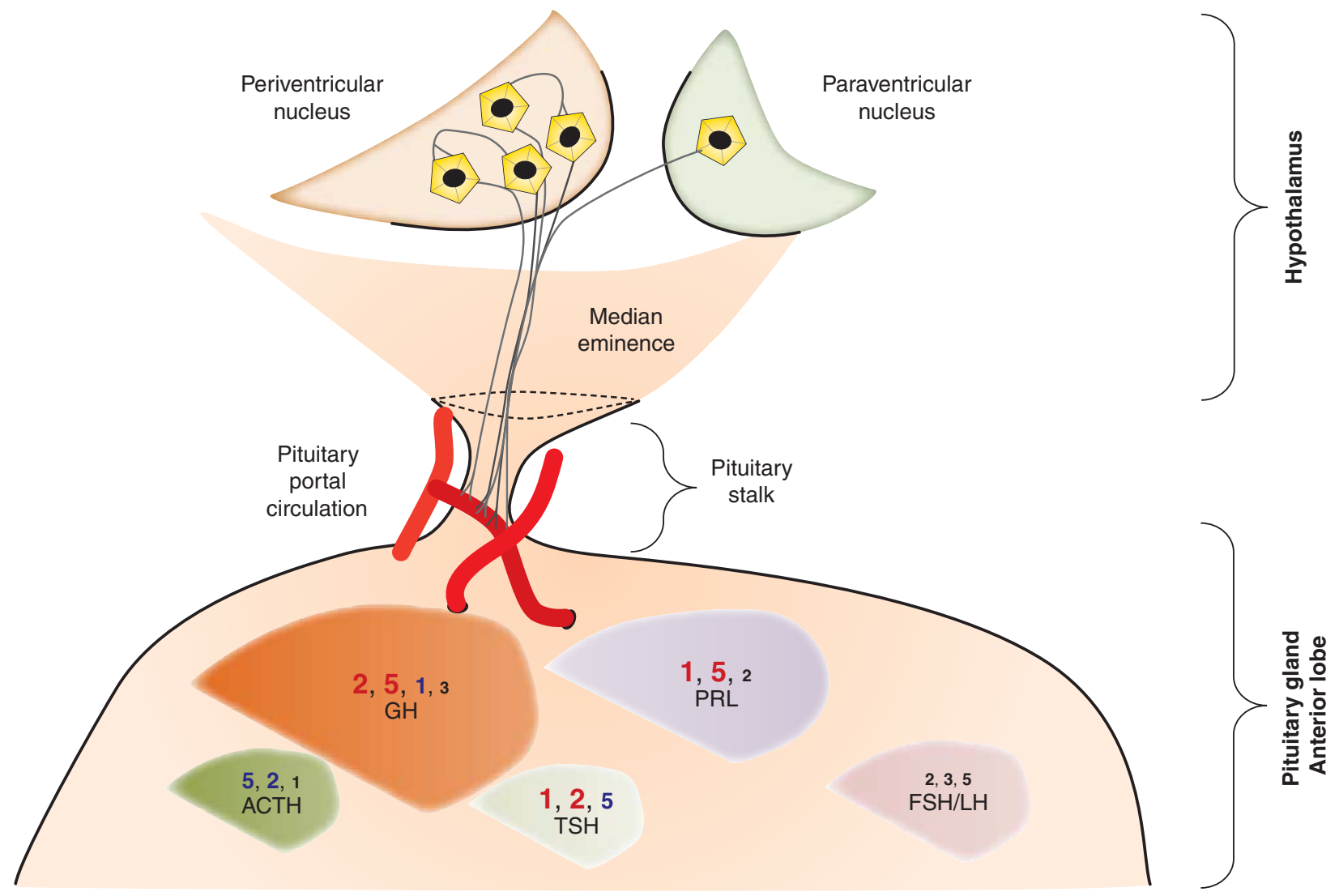

Figure 1

Somatostatin system: hypothalamus-anterior pituitary lobe axis. Somatostatinergic neuron bodies located at the hypothalamic periventricular $(80 \%)$ and paraventricular $(20 \%)$ nuclei travel through the median eminence and pituitary stalk and secrete SRIF into the pituitary portal circulation, reaching the cells of the anterior pituitary gland. Receptor subtype distribution is represented by subtype numbers (1-5) inside the specific cell type and is based on receptor profile in cell-respective human tumors, i.e. GH-, ACTH-, PRL, TSH-secreting adenomas and non-functioning pituitary tumors that also include gonadotroph FSH/LH secreting tumors. Large size red letter indicates that $\sim 90 \%$ of selective tumor type are positive for that receptor subtype, medium size blue letter indicate that $\sim 70 \%$ of selective tumor types are positive for that receptor subtype, small size black letters that $\sim 50 \%$ of selective tumor type are positive for that receptor subtype. Lower percentages are not presented. Receptor profile data is based on Ben-Shlomo \& Melmed (2010). http://jme.endocrinology-journals.org DOI: 10.1530/JME-14-0034 (c) 2014 Society for Endocrinology Printed in Great Britain
Published by Bioscientifica Ltd. 


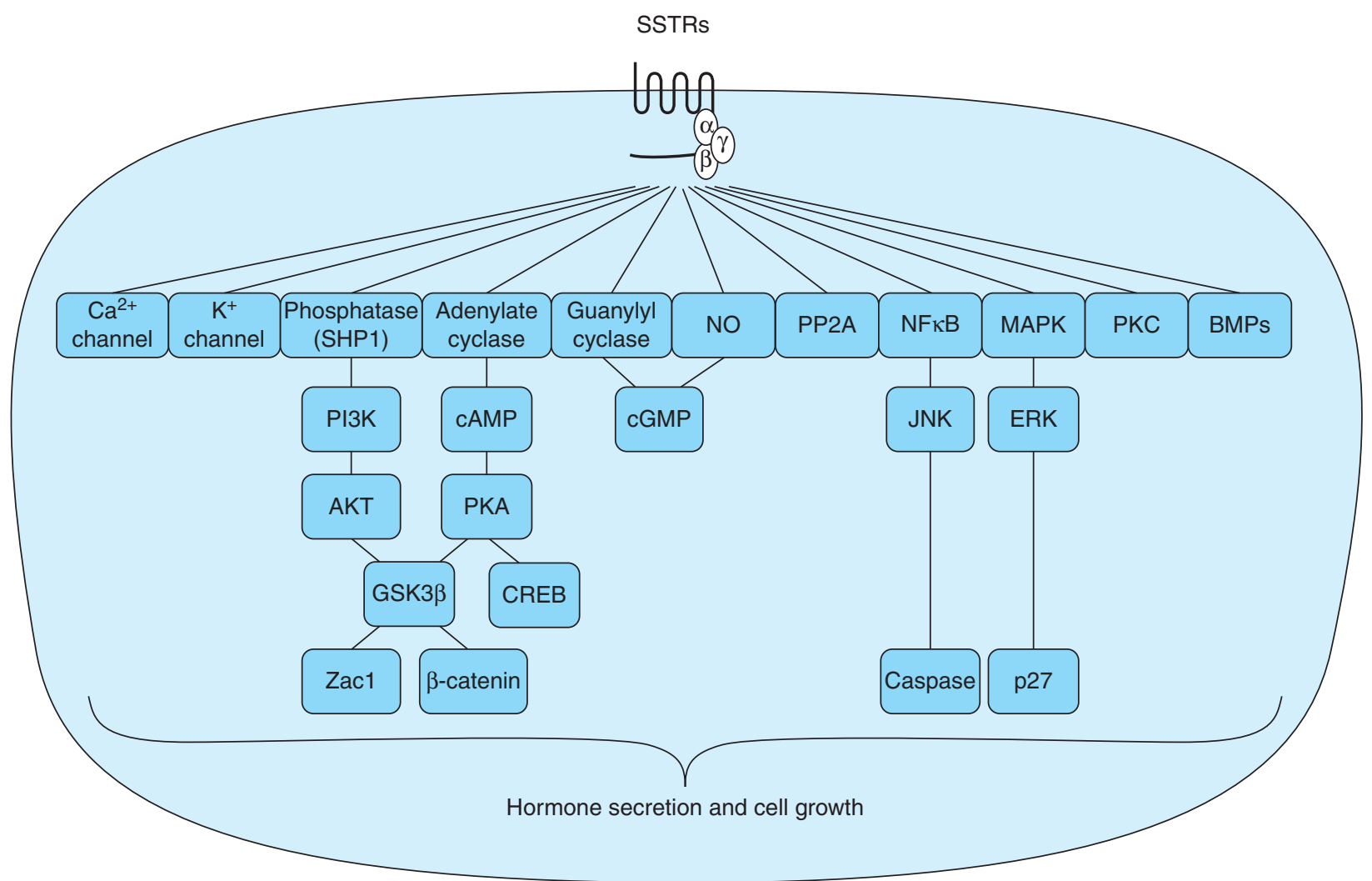

\section{Figure 2}

Selected SRIF-dependent pituitary signaling pathways. SRIF and SRIF analogs activate multiple molecular signaling pathways depicted here, which control pituitary hormone secretion as well as cell growth. These

convertases (Galanopoulou et al. 1995); however, SRIF-14, which contains 14 amino acids, is the predominant form of SRIF in the brain, including the hypothalamus (Acunzo et al. 2008), and therefore the predominant pituitary regulator.

Multiple factors regulate hypothalamic SRIF-14 production and secretion. Table 1 lists factors demonstrated to have a direct effect on hypothalamic SRIF production and/or secretion. Of note, most studies utilized either ex vivo hypothalamic slices or hypothalamic primary cell cultures, attempting to isolate the effects of the studied molecule on SRIF.

SRIF half-life is short $(\sim 2 \mathrm{~min})$ as it is rapidly internalized and inactivated by peptidases inside the cell after internalization (Roosterman et al. 2008) and in the circulation (Werle \& Bernkop-Schnurch 2006). To overcome this limitation for clinical use, analogs such as octreotide (Bauer et al. 1982), lanreotide (Sassolas et al. 1989), and pasireotide (Bruns et al. 2002) were synthesized as stable SRIF agonists. include $\mathrm{Ca}^{2+}$ and $\mathrm{K}^{+}$channels, phosphatases such as SHP1 and PP2A, cyclic nucleotide synthases such as guanylyl and adenylyl cyclase, nitric oxide, $\mathrm{NF} \kappa \mathrm{B}, \mathrm{MAPK} / \mathrm{ERK}, \mathrm{PKC}$, as well as BMPs.

SRIF regulates pituitary function through the G-protein-coupled receptors (GPCRs): SRIF receptor subtype 1 (sst1), sst2, sst3, and sst5. The expression of sst4 in the normal adult pituitary gland remains unclear. Although sst2 is alternatively spliced to sst2a and sst2b, only the sst2a isoform is expressed in the human pituitary tumors (Panetta \& Patel 1995). The five human SSTR genes are located on five different chromosomes and encode receptor protein of size ranging from 356 to 391 amino acid residues with $39-57 \%$ sequence identity among the receptors (homology derives mostly from the transmembranal domain; Patel 1999). Multiple factors that regulate SSTR expression levels (Ben-Shlomo \& Melmed 2010) are provided in Table 2.

SRIF-14 exhibits high binding affinity (few hundreds pM in membrane extracts from cell transfectants in vitro) to all receptor subtypes (Patel 1999). Upon ligand binding, the receptors bind the $G_{\alpha i / o}$ subunit of the $G_{\alpha \beta \gamma}$ tetramer, releasing $G_{\beta \gamma}$, initiating multiple cascades of signaling pathways. Most studies on SRIF-14 regulation of pituitary

Published by Bioscientifica Ltd 
Table 1 Molecules regulating hypothalamic SRIF production

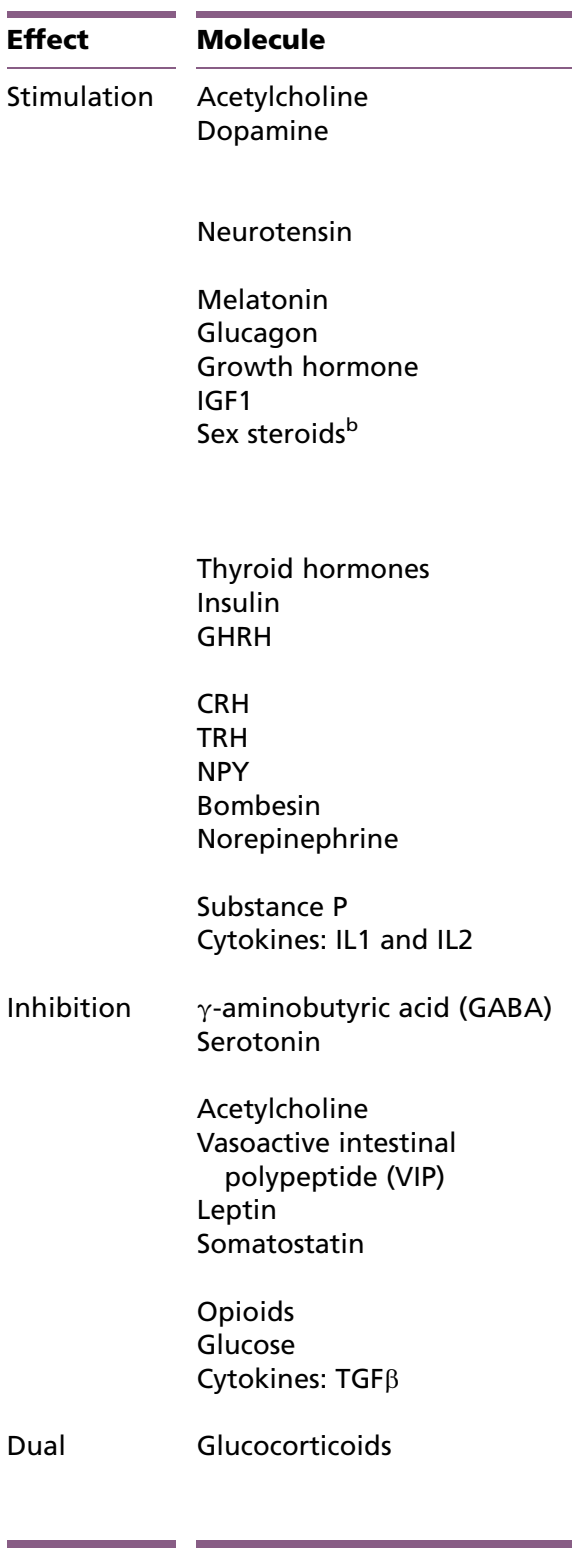

\section{Method utilized $^{\mathrm{a}}$}

Rat fetal hypothalamic primary cultures (d18)

Male rat hypothalamic segments

Rat hypothalamic segments

Rat hypothalamic segments

Perfused hypothalamic halves of male rats

Rat hypothalamic segments

Rat hypothalamic segments

In vivo and in vitro approaches. SRIF mRNA, protein, or hypothalamic neuron number

Rat hypothalamic segments

Rat hypothalamic segments

Cultured fetal rat hypothalamic cells

Cultured fetal rat hypothalamic cells

Cultured fetal rat hypothalamic cells

Rat hypothalamic segments

SRIF in the hypophysial portal blood

Dispersed adult male rat hypothalamic cells

Rat hypothalamic segments

Dispersed fetal rat diencephalic cells; mediobasal hypothalamus section

Rat fetal hypothalamic primary cultures (d18)

Rat fetal hypothalamic primary cultures (d18)

Male rat hypothalamic segments

Perfused hypothalamic halves of male rats

Fetal rat neurons in monolayer culture

Rat hypothalamic periventricular nucleus fragments

Rat hypothalamic fragments

Rat hypothalamic segments

Primary monolayer cultures of hypothalamic cells

In vivo injection induced while in vitro hypothalamic segment perfusion decreased SRIF secretion

\section{References}

Peterfreund \& Vale (1983)

Negro-Vilar et al. (1978), Maeda \&

Frohman (1980) and Lengyel et al. (1985)

Sheppard et al. (1979), Maeda \& Frohman

(1980) and Shimatsu et al. (1982)

Richardson et al. (1981)

Shimatsu et al. (1982)

Sheppard et al. (1978)

Berelowitz et al. (1981)

Werner et al. (1988), Zorrilla et al. (1990),

Senaris et al. (1992), Simonian et al.

(1998), Pillon et al. (2004) and Zhang

et al. (2009)

Berelowitz et al. (1980)

Berelowitz et al. (1982)

Iwasaki et al. (1987) and

Richardson et al. (1988)

Iwasaki et al. (1987)

Iwasaki et al. (1987)

Korbonits et al. (1999)

Abe et al. (1981)

Negro-Vilar et al. (1978) and

Richardson \& Twente (1990)

Sheppard et al. (1979)

Scarborough et al. (1989), Honegger et al. (1991) and Karanth et al. (1993)

Peterfreund \& Vale (1983)

Richardson et al. (1981) and

Peterfreund \& Vale (1983)

Richardson et al. (1980)

Shimatsu et al. (1982)

Quintela et al. (1997a)

Aguila (1998)

Lengyel et al. (1985)

Berelowitz et al. (1982)

Quintela et al. (1997b)

Estupina et al. (1997)

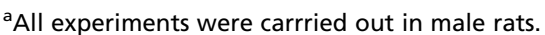

bSome report decreased somatostatin level following sex steroid treatment (Fernandez et al. 1992, Hassan et al. 2001). This discrepance may be due to the experimental approach including whether treatment was conducted in vivo or in vitro, treatment duration and dose, sex of the animal model and species.

function have focused on sst2 and sst5; however, the adult pituitary gland expresses sst1 and sst 3 that are yet to be explored in this context. Although SRIF signaling pathways in non-pituitary cells have been extensively investigated, with more than 20 such intracellular pathways described (Cervia \& Bagnoli 2007), pituitary SRIF-mediated molecular signaling pathways has been mostly limited to ion channel regulation, adenylate cyclase/cAMP/PKA regulated pathways, and protein phosphatase activation (Ben-Shlomo \& Melmed 2010).

\section{SRIF-dependent pituitary molecular signaling pathways}

SRIF-14 signaling in the anterior pituitary gland primarily mediates the regulation of hormone secretion, yet also plays a role in regulation of cell growth (Fig. 1).

\section{Ion channel regulation}

The dominant function of SRIF-dependent pituitary signaling is the inhibition of stimulated hormone secretion.

Published by Bioscientifica Ltd 
Table 2 Factors regulating pituitary cell SRIF receptor expression ${ }^{a}$. Table adapted and updated from Trends in Endocrinology \& Metabolism, 21, A Ben-Shlomo \& S Melmed, Pituitary somatostatin receptor signaling, 123-133, copyright (2010), with permission from Elsevier

\begin{tabular}{l}
\hline Treatment \\
\hline SRIF 14 ( $>24 \mathrm{~h})$ \\
High dose SRIF $(4 \mathrm{~h})$ \\
Low dose SRIF $(4 \mathrm{~h})$ \\
Forskolin \\
PKC activator (TPA) \\
GHRH \\
Ghrelin \\
17 $\beta$-estradiol \\
Testosterone \\
Thyroxine \\
Glucocorticoids $(2 \mathrm{~h})$ \\
Glucocorticoids ( $24-48 \mathrm{~h})$ \\
Progesterone \\
Food deprivation \\
Diabetes mellitus \\
TGF $\beta$
\end{tabular}

\begin{tabular}{c}
\hline sstr-1 \\
\hline+ \\
+ \\
+ \\
+
\end{tabular}

\begin{tabular}{c} 
sstr-2 \\
\hline+ \\
+ \\
0 \\
+
\end{tabular}

\begin{tabular}{c}
\hline sstr-3 \\
\hline+ \\
0 \\
0 \\
NA
\end{tabular}

\begin{tabular}{c}
\hline sstr-4 \\
\hline+ \\
0 \\
0 \\
NA
\end{tabular}

$\stackrel{+}{0 /+}$$$
\begin{gathered}
0 \\
0 /+
\end{gathered}
$$

\section{0}

0/+

o/-

NA

NA

$-1+$

$+$

$+$

NA

NA

\begin{tabular}{c}
\hline sstr-5 \\
\hline+ \\
+ \\
- \\
$0 /-$
\end{tabular}

$\begin{array}{cc}0 /+ & 0 /+ \\ + & \text { NA } \\ + & + \\ - & -\end{array}$

+
NA
0

NA

- then +

\section{NA}

NA

0

NA

0

0/-

$0 /-$

$+1-$

$\begin{array}{ll}+ & 0 \\ - & - \\ - & - \\ \text { NA } & +\end{array}$

-
-
-
NA

NA

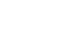

\section{References}

Berelowitz et al. (1995) and Luque et al. (2004)

Cordoba-Chacon et al. (2012)

Cordoba-Chacon et al. (2012)

Patel et al. (1993), Luque et al. (2004) and

Cordoba-Chacon et al. (2012)

Cordoba-Chacon et al. (2012)

Luque et al. (2004), Park et al. (2004) and Cordoba-Chacon et al. (2012)

Luque et al. (2004), Yan et al. (2004) and Cordoba-Chacon et al. (2012)

Xu et al. (1995), Djordjijevic et al. (1998), Kimura et al. (1998), Canosa et al. (2003) and Cardenas et al. (2003)

0 Xu et al. (1995)

$+\quad$ James et al. (1997)

NA Xu et al. (1995)

0 Xu et al. (1995), Petersenn et al. (1999) and van der Hoek et al. (2005)

$\begin{array}{ccl}\text { NA } & \text { NA } & \text { Xu et al. (1995) } \\ 0 & 0 & \text { Berelowitz et al. (1995) } \\ 0 & - & \text { Berelowitz et (1995) }\end{array}$

$0 \quad-\quad$ Berelowitz et al. (1995)

NA NA Puente et al. (2001)

+ , Upregulation of receptor expression; -, downregulation of receptor expression; 0, no change in receptor expression; NA, not assessed.

a'This table incorporates results from different species (pig, rat, and fish, baboon), genders, and assay techniques (in vitro and in vivo, primary cultures and cell-lines, mRNA transcripts, and promoter activation measurements); therefore an integrated interpretation is difficult.

Hypothalamic hormones (Bjoro et al. 1987, Spada et al. 1990, Bonnefont et al. 2000, Liu et al. 2006, TsanevaAtanasova et al. 2007) signal to release anterior pituitary hormone secretion by increasing intracellular $\mathrm{Ca}^{2+}$ levels, resulting in the exocytosis of hormone-containing vesicles. Most information related to SRIF-mediated ion channel regulation was accrued through the investigation of mechanisms for SRIF-dependent inhibition of $\mathrm{GH}$ secretion. Although the definitive role of individual ion channels in regulation of hormone secretion are not fully understood, advances have been made through the use of electro-physical methods in addition to molecular biological approaches. $\mathrm{Na}+, \mathrm{Ca}^{2+}$, and $\mathrm{K}^{+}$channels have been isolated in somatotroph cell membranes and described to contribute to hormone secretion.

GH secretion is activated upon GH-releasing hormone (GHRH) binding and activation of somatotroph cell surface receptors. GHRH signaling causes membrane depolarization and an action potential burst in response to the opening of tetrodotoxin-insensitive $\mathrm{Na}^{+}$channels. In turn, increased $\mathrm{Ca}^{2+}$ transient frequency and intracellular $\mathrm{Ca}^{2+}$ concentration lead to amplified exocytosis of GH-containing granules (Tsaneva-Atanasova et al. 2007). In contrast, SRIF antagonizes the effect of GHRH through membrane hyperpolarization by opening $\mathrm{K}^{+}$ channels leading to depletion of intracellular $\mathrm{Ca}^{2+}$ concentration, effectively inhibiting GH exocytosis (Kraicer \& Spence 1981, Draznin et al. 1988, White et al. 1991, Tsaneva-Atanasova et al. 2007). SRIF signaling through sst2 and sst4 activates $\mathrm{K}^{+}$influx through both inwardly rectifying channel conductance and delayed rectifying $\mathrm{K}^{+}$channels in $\mathrm{GH}_{3}$ cells (Yang et al. 2005, 2007, Yang \& Chen 2007). SRIF targets the largeconductance, calcium- and voltage-activated $\mathrm{K}^{+}$channels (BK channel) in $\mathrm{GH}_{4} \mathrm{C}_{1}$ cells (White et al. 1993). Ultimately, these effects result in membrane hyperpolarization and closure of $\mathrm{L}$ - and N-type voltage sensitive calcium channels (Petrucci et al. 2000, Cervia et al. 2002a, Tsaneva-Atanasova et al. 2007, Yang et al. 2007). SRIFreduced T-type current occurs primarily in rat somatotroph cultures (Chen et al. 1990, Yang et al. 2007). In somatotroph cells, SRIF regulation of $\mathrm{K}^{+}$currents are mediated by $\mathrm{G}_{\mathrm{i} 3}$ (Chen 1997), while $\mathrm{Ca}^{2+}$ currents are mediated by $\mathrm{G} \alpha_{\mathrm{o} 2}$ (Chen 1997, Degtiar et al. 1997), $\beta 1, \beta 3$ (Kleuss et al. 1992), and $\gamma 3$ (Kleuss et al. 1993). In human GH-secreting tumor cultures, sst5-specific signaling is dependent on $\mathrm{G} \alpha_{\mathrm{o} 1}$ (Peverelli et al. 2013).

SRIF-mediated inhibition of corticotropinreleasing hormone (CRH)-stimulated $\mathrm{Ca}^{2+}$ levels in human corticotropin-secreting pituitary adenomas is

Published by Bioscientifica Ltd 
effectively blocked by pretreatment with pertussis toxin (PTX), indicating that the effect is $\mathrm{G} \alpha_{\mathrm{i} / \mathrm{o}}$ dependent (Spada et al. 1990). SRIF-induced $\mathrm{K}^{+}$influx is regulated by $\mathrm{G}_{\mathrm{i} 3}$ in AtT-20 corticotroph cells (Takano et al. 1997). Although it remains to be determined whether SRIF regulates pituitary $\mathrm{Ca}^{2+}$ levels independently of $\mathrm{K}^{+}$channels, GH release correlates with both frequency and amplitude of calcium oscillations, while calcium channel blockers and SRIF acutely suppress $\mathrm{Ca}^{2+}$ extrusion (Holl et al. 1988). SRIF treatment resulted in $\mathrm{Ca}^{2+}$-dependent redistribution of cytoplasmic microfilaments, without affecting intracellular somatotroph GH content (Shimada et al. 1990), in addition to reduced association of exocytosis-associated RAB3B and SNARE proteins (Matsuno et al. 2003). Finally, it has been recently shown that SRIF inhibited CaMKii $\beta$ expression and protein levels, and knockdown of CaMKii $\beta$ decreases $\mathrm{Ca}^{2+}$ levels in GC cells and suppressed secretion, suggesting that CaMKii $\beta$ may mediate SRIF regulation of $\mathrm{Ca}^{2+}$ (Cervia 2011). In summary, although the role of SRIF-dependent regulation of ion channels in pituitary cell growth is unknown, SRIF-dependent regulation $\mathrm{K}^{+}$-derived membrane hyperpolarization and the reduction of $\mathrm{Ca}^{2+}$ influx and concentration mediate the acute regulation of the exocytosis of hormonecontaining vesicles.

\section{Adenylate cyclase/cAMP/PKA signalling}

SRIF inhibits pituitary adenylate cyclase/cAMP/PKA signaling, thereby inhibiting pituitary hormone synthesis and cell growth. SRIF inhibits cAMP production and ACTH secretion induced by CRH, forskolin, isoproterenol, vasoactive intestinal polypeptide (VIP), and cholera toxin in AtT-20 cells (Heisler et al. 1982). Similarly, SRIF inhibits cAMP and GH production induced by GHRH stimulation in primary pituitary cells (Bilezikjian \& Vale 1983). SRIF inhibits forskolin-induced cAMP/PKA signaling pathway in rat somatotropic cells (Tentler et al. 1997). sst1, sst2, sst3, and sst5 all mediate SRIF inhibition of adenylate cyclase in pituitary cells (Tentler et al. 1997, Cervia et al. 2003, Ben-Shlomo et al. 2005). SRIF inhibited forskolin-induced cAMP production, PKA activation, CREB phosphorylation, and transcription potency, while overexpression of the PKA catalytic subunit suppressed SRIF action in sst2 stable transfectant $\mathrm{GH}_{4}$ cells (Tentler et al. 1997).

The ability of SRIF to inhibit adenylate cyclase is $\mathrm{G}_{\mathrm{\alpha i} / \mathrm{o}^{-}}$ dependent (Koch et al. 1985, Tallent \& Reisine 1992, Liu et al. 1994, Morishita et al. 2003). In $\mathrm{GH}_{4} \mathrm{C}_{1}$ cells, SRIF-action is mediated specifically via $\mathrm{G} \alpha_{\mathrm{i} 2}$ (Liu et al. 1994), as PTX suppresses SRIF-mediated inhibition of VIPinduced cAMP (Koch et al. 1985). PTX treatment similarly attenuated SRIF action in $\mathrm{GH}_{4}$ cells overexpressing sst2 (Tentler et al. 1997). In addition, PTX attenuated SRIFdependent inhibition of GHRH-induced GH in MtT/SGL somatotroph cells (Morishita et al. 2003). sst5-specific inhibition of forskolin-stimulated cAMP accumulation was dependent on $\mathrm{G} \alpha_{\mathrm{O} 1}$ in human GH-secreting tumor primary cultures (Peverelli et al. 2013). In AtT-20 cells, SRIF inhibition of adenylate cyclase and ACTH secretion is $\mathrm{G} \alpha_{\mathrm{i} 1}$-dependent (Tallent \& Reisine 1992). sst2, sst3, and sst5 mediate SRIF-dependent inhibition of cAMP in AtT-20 cells (Ben-Shlomo et al. 2005), as does sst1 in GC cells (Cervia et al. 2003). In chicken pituitary cells, SRIF inhibited GHRH-induced GH release by inhibiting cAMP/PKA signaling independent of calcium or protein kinase C (Donoghue \& Scanes 1991). Although SRIF is classically an inhibitor of adenylate cyclase activity, there are reports using primary porcine somatotroph cultures in which both low and high doses of SRIF increased cAMP levels, suggesting a possible dual dose-dependent effect (Ramirez et al. 2002). As the mechanism by which this phenomenon occurs remains elusive, perhaps SSTRs, such as other GPCRs, might interact with not only $G \alpha_{\mathrm{i} / \mathrm{o}}$ proteins but also $G \alpha_{s}$ depending on the ligand context and receptor conformation. Therefore, SRIF-mediated inhibition of pituitary hormone secretion is both $\mathrm{Ca}^{2+}$ and cAMP dependent; as both $\mathrm{Ca}^{2+}$ concentration and cAMP levels are $G \alpha_{i}$ dependent, it is difficult to determine the relative contribution of each to hormone secretion and whether these mechanisms occur independently of each other.

\section{Protein phosphatase pathways}

SRIF-mediated regulation of pituitary protein phosphatase pathways is primarily associated with mechanisms controlling cell growth. SRIF is associated with increased protein phosphatase activity in both human GH-secreting pituitary adenoma cells and rat cell lines as well as human non-functioning pituitary tumors (Cervia \& Bagnoli 2007). SRIF increases tyrosine phosphatase activity and was associated with the inhibition of cell growth in human GH-secreting pituitary tumor cells in vitro (Florio et al. 2003), while serine/threonine phosphatase activity participates in SRIF-mediated regulation of $\mathrm{Ca}^{2+}$ influx through dephosphorylation of $\mathrm{Ca}^{2+}$ and $\mathrm{K}^{+}$ voltage-activated (BK) channels (White et al. 1991). Octreotide exhibited antiproliferative effects in $\mathrm{GH}_{3}$ cells, mediated by both PTX-dependent and SHP1

Published by Bioscientifica Ltd. 
(but not SHP2)-dependent mechanism (Theodoropoulou et al. 2006, Cerovac et al. 2010). Octreotide induced SHP1dependent inhibition of the PI3K activity leading to the inhibition of PDK1 and Akt activity, ultimately leading to enhanced glycogen synthase kinase $3 \beta$ (GSK3 $\beta$ ) activity and upregulation of the tumor suppressor ZAC1 (ZACN; Theodoropoulou et al. 2006). Octreotide also increased the levels of rapamycin-suppressed phosphorylated insulin receptor substrate 1 , subsequently decreasing phosphorylation of Akt through SHP1 (Cerovac et al. 2010). Interestingly, in acromegaly patients treated with octreotide, ZAC1 immunoreactivity correlated with insulin-like growth factor 1 (IGF1) normalization and tumor shrinkage (Theodoropoulou et al. 2009). Both octreotide and an sst2-specific agonist (BIM23120) induced apoptosis, and apoptosis-associated gene expression in human GH-secreting tumors is blocked by vanadate, indicating the involvement of protein phosphatases (Ferrante et al. 2006). Vanadate similarly inhibited SRIF and lanreotideinduced growth arrest in primary cultures of nonfunctioning pituitary adenomas (Florio et al. 1999). The role of SRIF-mediated regulation of protein phosphatase activity and growth arrest in non-pituitary cells has been described (Florio 2008). As, clinically, SRIF analog therapy induces pituitary tumor shrinkage, the mechanisms involved in SRIF-mediated protein phosphatase activation require further investigation. Moreover, the contribution of individual SSTR subtypes to phosphatase activation is still unclear.

\section{Other SRIF-dependent pituitary pathways}

Several other signaling pathways have been described to mediate SRIF action (Cervia \& Bagnoli 2007, Otsuka et al. 2012), including MAPK, guanylyl cyclase, PKC, nitric oxide (NO), PI3K/Akt, and bone morphogenetic proteins (BMPs). The physiological relevance of these pathways to pituitary cell growth and hormone secretion remains unclear. Both octreotide and pasireotide decreased MAP$\mathrm{K} / \mathrm{ERK}$ phosphorylation in both $\mathrm{GH}_{3}$ cells and in GH-secreting tumor cultures, and upregulated $\mathrm{p} 27^{\mathrm{Kip}}$ expression (Hubina et al. 2006), while knockdown of sst5 increased ERK phosphorylation in AtT-20 cells (Ben-Shlomo et al. 2007). In human GH-secreting tumor cultures, sst5dependent inhibition of ERK phosphorylation was dependent on $\mathrm{G} \alpha_{\mathrm{o} 1}$ (Peverelli et al. 2013). Octreotide activated PI3K/Akt and MAPK pathways through sst2 and sst5 in GH-secreting cells, inducing histone methyltransferases associated with menin, resulting in the upregulation of $\mathrm{p} 27^{\mathrm{Kip}}$ and cell cycle arrest (Horiguchi et al. 2009). These discrepancies may suggest cell-type specificity or perhaps a similar dual role for SRIF action as that for adenlylate cyclase regulation. SRIF was also shown to exhibit a dual dose-dependent effect on pituitary guanylyl cyclase regulation and cGMP accumulation (Vesely 1980).

SRIF inhibited both PKC-induced stimulation of GH secretion (Ikuyama et al. 1987) and NO-induced cGMP and GH levels (Bocca et al. 2000, Luque et al. 2005). SRIF blocked phospholipase A2-mediated GHRHand thyrotropin-releasing hormone (TRH)-induced pituitary arachidonate release (Judd et al. 1986) and decreased arachidonate levels in GC cells (Cervia et al. $2002 b$ ). SRIF was also shown to induce apoptosis through $\mathrm{NF} \kappa \mathrm{B} / \mathrm{JNK} /$ caspase pathway (Ferrante et al. 2006, Guillermet-Guibert et al. 2007), and inhibited vascular endothelial growth factor production levels in pituitary tumor cells (Lohrer et al. 2001, Zatelli et al. 2007). SRIF antagonized CRH-dependent inhibition of GSK3 $\beta$ activity in AtT-20 cells, inhibiting Wnt/ $\beta$-catenin-mediated transcription and cell growth in a cAMP-dependent manner (Khattak et al. 2010). SRIF action in AtT-20 cells is dependent on BMP signaling. Inhibitory effects of octreotide and pasireotide on CRH-induced secretion in AtT-20 cells were attenuated by noggin, an inhibitory BMPbinding protein, suggesting that the endogenous BMP system is functionally linked to the mechanism of SRIFmediated inhibition of secretion (Tsukamoto et al. 2010). SRIF-signaling in $\mathrm{GH}_{3}$ cells was similarly shown to be dependent on BMPs (Tsukamoto et al. 2011). Although it is evident that kinases and BMP growth factors are involved in pituitary SRIF signaling, our understanding of their regulation and functional consequences remain unclear.

\section{Receptor phosphorylation, internalization, and desensitisation}

Following activation of SSTRs by ligand, a feedback mechanism is activated leading to the receptor phosphorylation and internalization, ultimately initiating receptor desensitization and attenuated receptor-related signaling. As of yet, the only SSTR subtype described to follow this process in pituitary cells is sst2. sst2 was phosphorylated and internalized after treatment with SRIF and sst2-specific agonists in stable sst2 transfectant GH4C1 cells (Hipkin et al. 1997). sst2 is phosphorylated at five serine and threonine residues within the C-terminus following SRIF treatment (Liu et al. 2009). Moreover, in transiently transfected $\mathrm{GH}_{3}$ cells, both SRIF and octreotide, but not pasireotide, induced robust sst2 phosphorylation. Pasireotide stimulated selective residue

Published by Bioscientifica Ltd. 
phosphorylation only upon GRK2 and GRK3 overexpression, yet resulted in only weak $\beta$-arrestin-sst 2 complexes that easily dissociated (Poll et al. 2010). Prolonged SRIF stimulation leads to sst2 desensitization in both $\mathrm{GH}_{4} \mathrm{C}_{1}$ and AtT-20 cells (Hipkin et al. 1997), leading to attenuated responses to SRIF inhibition of cAMP production, and enhanced forskolin and CRH induction of adenylate cyclase and cAMP levels (Reisine \& Axelrod 1983, Presky \& Schonbrunn 1988, Ben-Shlomo et al. 2009).

While sst1 does not internalize (Sarret et al. 1999), there are conflicting reports regarding sst5 internalization. One study using transient sst5 transfectant $\mathrm{GH}_{3}$ cells found that the third intracellular loop of sst 5 was involved in receptor phosphorylation and internalization following $\beta$-arrestin 2 binding (Peverelli et al. 2008). Yet, sst5 did not internalize following treatment with either SRIF or sst5specific agonists in stable AtT-20 transfectants (Sarret et al. 1999, Ben-Shlomo et al. 2005). SRIF desensitization in stable receptor transfectant AtT-20 cells was dependent on sst 2 and not sst5, as sst5 did not internalize in these cells (Ben-Shlomo et al. 2009). sst5 expression is unaffected by sst5 agonists or pasireotide in AtT-20 cells (van der Hoek et al. 2005, Ben-Shlomo et al. 2009), suggesting that sst5 remains biologically active in the membrane longer than sst2. In vitro studies may not accurately represent patterns of SRIF-dependent SSTR subtype-specific internalization and desensitization in vivo and therefore requires further study.

Any pituitary cell may express multiple sst receptor subtypes on the cell surface (Ben-Shlomo \& Melmed 2010), suggesting that in addition to receptor subtypespecific signaling, receptor subtypes may form heterodimers, which may govern pituitary cell response to SRIF and SRIF analogs. Although sst receptor dimerization has yet to be demonstrated in pituitary cells lines, there is evidence of sst receptor hetero-dimerization when receptors are stably overexpressed in non-pituitary cell lines, and that dimerization does effect sst receptor function (Pfeiffer et al. 2002, Grant et al. 2008, War \& Kumar 2012). While sst receptor subtypes are structurally and sequentially conserved throughout the body, it is likely that variation in receptor subtype expression contributes to the tissue specificity of SRIF-mediated molecular signaling, and should be further evaluated.

\section{SRIF-dependent pituitary hormone secretion}

SRIF exerts a primary effect on pituitary cells through acute inhibition of hormone secretion, specifically by suppressing exocytosis of hormone-containing vesicles.
Although, it remains unclear whether SRIF-dependent inhibition of secretion is partially contingent on inhibition of cell growth arrest, as they usually occur concurrently following SRIF analog treatment of somatotroph tumors, there are reports of asynchronous hormone secretion and tumor shrinkage (Colao et al. 2009). In one such tumor, expression of sst5 was higher than sst 2 levels, suggesting the potential of subtype-specific regulation of hormone secretion vs antiproliferative effects (Resmini et al. 2007).

Although SRIF is the primary inhibitor of pituitary GH secretion and is the main focus of this review, it should be noted that the neuropeptide CST, which shares structural homology to SRIF, has been reported to exhibit a similar inhibitory effect as SRIF on GH secretion both in vitro and in vivo (Broglio et al. 2002), yet the mechanism of action remains unclear as CST is reported to bind not only to SSTRs but also to the ghrelin receptor (GHS-R; Broglio et al. 2002). In contrast to the inhibitory role of CST on GH secretion, CST is reported to increase PRL release (Baranowska et al. 2009, Cordoba-Chacon et al. 2011). Unlike SRIF, CST has not been shown to be secreted from the hypothalamus directly into the pituitary portal system, and the exact role of CST in endocrine regulation of pituitary function in vivo is yet to be demonstrated.

\section{GH secretion}

The classical outcome of SRIF/sst signaling is the inhibition of hormone secretion, particularly that of GH from pituitary somatotroph cells (Giustina \& Veldhuis 1998). Multiple factors and feedback loops regulate the release of SRIF from the hypothalamus and ultimately the control of GH secretion, including serum GH/IGF1 and glucose, as well as immobilization and exercise (Giustina \& Veldhuis 1998). As SRIF inhibits GHRH-induced GH transcription and secretion by suppressing exocytosis of hormonecontaining granules (Patel \& Srikant 1986, Tentler et al. 1997, Morishita et al. 2003, Farhy \& Veldhuis 2004), SRIF-null mice were expected to exhibit the characteristics of GH excess. However, despite moderately elevated GH levels, serum IGF1 levels were slightly elevated; however, body length and weight and IGF1 levels were unchanged (Low et al. 2001, Zeyda et al. 2001). Targeted hypothalamic delivery of lentiviral-shRNA against SRIF in young mice led to increased GH protein levels without effecting GH mRNA levels, yet serum levels of SRIF, GH, and IGF1, as well as body weight, were unchanged (Hao et al. 2010). These studies suggest that although SRIF may play an important function as an acute inhibitor of GHRH-induced

Published by Bioscientifica Ltd. 
GH secretion, it may have a less significant role in regulation of basal GH secretion.

While direct inhibition of pituitary hormone transcription has yet to be definitively associated with SRIF signaling, as some studies demonstrate a SRIF-dependent decrease in GH mRNA levels (Sugihara et al. 1993, Tsukamoto et al. 1994, Acunzo et al. 2008) others describe no change (Simard et al. 1986, Davis et al. 1989, Namba et al. 1989, Tanner et al. 1990, Gruszka et al. 2007), and some even demonstrate upregulation of gene expression possibly reflecting a $\mathrm{GH}$-rebound effect after termination of SRIF treatment; the latter exemplifies the importance of outcome measurement timing. SRIF did not affect GH mRNA expression, but did suppress intracellular GH protein levels and decreased GH secretion in primary rat anterior pituitary cells (Simard et al. 1986). Similarly, SRIF inhibited GH secretion without affecting GH mRNA expression in primary human GH-secreting tumors cells (Davis et al. 1989). In cultured bovine pituitary cells, SRIF was able to suppress GHRH-induced GH expression, but had no effect on untreated cells (Tanner et al. 1990). Moreover, while sst2-specific and sst5-specific agonists suppressed GH secretion in human GH-secreting tumors, they did not affect GH transcription (Gruszka et al. 2012). Nevertheless, transient overexpression of sst 2 in primary human GH secreting tumor cells modestly suppressed GH expression, in the absence of SRIF ligand (Acunzo et al. 2008).

Delineation of sst subtype-selective SRIF-mediated regulation of GH secretion remains unclear; however, both sst2 and sst5 and to a lesser extent sst1 play important roles in the inhibition of GH secretion. SRIF analog therapies targeting sst2 and/or sst 5 for treatment of patients with GH-secreting pituitary tumors are effective at reducing serum GH and normalizing serum IGF1 levels (Melmed 2006). Moreover, treatment using compounds with affinity for sst 2 and sst5 was $40 \%$ more effective at suppressing primary GH-secreting tumor GH secretion than sst 2 or sst5-selective agonists individually (Shimon et al. 1997a). Increased sst2 membrane density in GH-secreting tumor cells enhances the sensitivity to sst2selective agonists (Acunzo et al. 2008, Taboada et al. 2008). In normal fetal pituitary, both sst2 and sst5-specific agonists inhibit GHRH-induced GH secretion (Shimon et al. 1997b, Ren et al. 2003); however, co-treatment with sst2 and sst5-selective agonists was more effective than each individually (Ren et al. 2003). sst1-selective agonists similarly reduced GH secretion in both primary tumor cultures (Zatelli et al. 2003) as well as GC cells (Cervia et al. 2002a). Pasireotide, which binds all four receptor subtypes (sst5 $>$ sst $2>$ sst $3>$ sst 1 ), more effectively reduces serum GH levels in animal models compared with octreotide (sst2>sst5 $\gg s s t 3$, but not sst1), and was recently demonstrated to have some advantage over octreotide in patients with acromegaly (Colao et al. 2014); however, the longterm efficacy of one drug over the other is yet to be proven (Petersenn et al. 2014a,b) and is still under current investigation.

Importantly, recent reports demonstrate a concentration-dependent, cell-specific effect of SRIF on GH-secreting cells, in both bovine and primates. While high-concentrations of SRIF inhibit GH-secretion, lowconcentrations stimulate GH-secretion. sst1 and sst2 were shown to mediate the inhibitory effect of SRIF, while its stimulatory effect was signaled via sst5, all through adenylate cyclase-cAMP pathway and intracellular calcium level regulation. SRIF's dose-dependent stimulatory/inhibitory effects should be further studied as they may have an important role in the physiological regulation of somatotroph cells (Luque et al. 2006a, Cordoba-Chacon et al. 2012).

Surprisingly, despite the dominant role of sst2 and sst5 in SRIF-mediated inhibition of GHRH-induced GH secretion, Sst2 and Sst5-null mice do not exhibit elevated serum GH levels (Zheng et al. 1997, Norman et al. 2002, Luque et al. 2006b). These results are, however, consistent with a potential, yet unproven, compensatory function of sst1 or sst3 regulating GH secretion in the absence of sst2 and sst5. Conditional knockout mice may provide a model to further elucidate the subtype-specific role of sst receptor subtypes in SRIF-dependent inhibition of GH secretion.

\section{PRL secretion}

SRIF-dependent control of PRL secretion is modest compared with that of GH. Treatment of prolactinoma samples with sst5-selective agonists effectively inhibited PRL secretion without affecting PRL expression (Shimon et al. 1997a, Jaquet et al. 1999, Fusco et al. 2008, Gruszka et al. 2012), while octreotide had no effect, likely due to the fact that sst5 is the predominantly expressed receptor subtype in human prolactinoma samples (Jaquet et al. 1999). Similarly, while octreotide exerted only modest effects, pasireotide strongly suppressed PRL secretion in prolactinoma tumor cultures (Hofland et al. 2004). PRL secretion was reduced upon SRIF treatment as well as an sst1-specific agonist in PRL-secreting pituitary tumors; the degree of PRL suppression correlated with sst1 expression levels (Zatelli et al. 2003). BMP4 enhanced the attenuating effect of pasireotide, but not of octreotide, on

Published by Bioscientifica Ltd. 
forskolin-induced PRL in $\mathrm{GH}_{3}$ cells. Interestingly, BMP4 and BMP6 downregulated endogenous sst2 abundance, while increasing sst5 expression, and treatment with noggin rescued these effects. Moreover, noggin treatment increased octreotide sensitivity and decreased pasireotide sensitivity (Tsukamoto et al. 2011).

Several studies suggest that SRIF-dependent regulation of PRL secretion is estrogen-dependent. Female rats pretreated with $17 \beta$-estradiol $\left(\mathrm{E}_{2}\right)$ exhibited lanreotidedependent reduction in lactotroph cell density and PRL secretion (Schussler et al. 1994). $\mathrm{E}_{2}$ treatment sensitized PRL-secreting tumor cells to SRIF and octreotidedependent inhibition of PRL secretion, likely due to the upregulation of sst2 and sst3 (Visser-Wisselaar et al. 1997, Djordjijevic et al. 1998). Despite the inability of SRIF to inhibit PRL secretion in male rat primary lactotroph cultures, $\mathrm{E}_{2}$ treatment similarly sensitizes these cells to SRIF (Goth et al. 1996, Lee \& Shin 1996). In addition, SRIF inhibits PRL induction by estrogen in male-to-female transsexuals, even more so upon co-treatment with cyproterone acetate, a compound with anti-androgen characteristics (Gooren et al. 1984). Taken together, the regulation of PRL secretion through SRIF-dependent pathways appears to be receptor subtype specific, BMP dependent, and sensitive to the presence of estrogen.

\section{ACTH secretion}

The role of SRIF signaling in the regulation of ACTH secretion from pituitary corticotroph cells remains unclear. SRIF did not affect basal or CRH (Stafford et al. 1989), ghrelin (Broglio et al. 2002), or angiotensin II (Volpi et al. 1996)-stimulated ACTH or cortisol levels in humans. Nevertheless, studies suggest that SRIF regulates ACTH secretion and is dependent on cortisol levels and cell milieu (Hofland 2008). Although SRIF did not affect basal or CRH-stimulated ACTH secretion in normal rat pituitary cells (Brown et al. 1984, Kraicer et al. 1985), SRIF inhibited CRH- and vasopressin-induced ACTH secretion in cultured pituitary cells derived from adrenalectomized rats and in serum starved cultures (Hofland 2008). Increasing cortisol levels in cell medium downregulated sst2 but not sst5 expression in corticotroph tumor cells that express both receptors (van der Hoek et al. 2007, van der Pas et al. 2013). Pituitary corticotroph cells were sensitized to octreotide in a serum-free environment, as well as after inhibition of the glucocorticoid receptor, which also downregulates sst2 expression (Lamberts et al. 1989a).

Octreotide and lanreotide, both clinically used as sst2 agonists, were ineffective in treating patients with
Cushing's disease (Hofland 2008), but were able to suppress ACTH levels in patients with hypercortisol-emia such as those with adrenal insufficiency (Fehm et al. 1976) and Nelson's syndrome (Tyrrell et al. 1975, Lamberts et al. 1989b). However, pasireotide, which has preferential affinity for sst5, inhibits ACTH secretion in patients harboring ACTH-secreting adenoma despite hypercortisolemia (Colao et al. 2012). The significance of SRIF-mediated signaling, particularly through sst5, has been further delineated through investigation of Srifnull and Sst5-null mice models; Srif-null mice exhibit elevated levels of Pomc mRNA expression (Luque et al. 2006b), and sst5-null mice have increased basal serum ACTH and cortisol levels (Strowski et al. 2003).

Importantly, downregulation of sst2 may not be the sole explanation to octreotide resistance as the drug was less effective than pasireotide at reducing ACTH secretion even after normalization of cortisol levels and rescued sst2 expression in preoperative Cushing's patients (van der Pas et al. 2013). Therefore the contribution of other SSTRs expressed on corticotroph cells including sst3 and sst1 may play a role as well.

BMP signaling was shown to play a significant role in sst receptor-mediated inhibition of ACTH secretion in corticotroph cells. The BMP inhibitor noggin enhances CRH-induced ACTH secretion in AtT-20 cells and attenuated octreotide and pasireotide-mediated suppression of CRH-induced ACTH secretion. Octreotide and pasireotide increased BMP-Smad1/5/8 signaling and upregulated BMP type I and II receptors while simultaneously downregulating inhibitory Smad6/7 (Tsukamoto et al. 2010). In summary, SRIF-mediated regulation of ACTH secretion appears to be sst receptor subtype specific and dependent on serum cortisol levels. The role of sst1, sst3, and BMP signaling pathways in the regulation of ACTH secretion require further investigation.

\section{Gonadotropin secretion}

Knowledge of SRIF regulation of human LH and FSH secretion is limited as pituitary tumors arising from gonadotroph lineages do not usually secrete FSH or LH and therefore do no result in a phenotype associated with hormone hypersecretion (Greenman \& Stern 2009). Nevertheless, evidence suggests an inhibitory effect of SRIF on gonadotropin secretion. SRIF infusion suppressed gonadotropin-releasing hormone (GNRH)-induced LH and FSH in normal men (Millar et al. 1982) and inhibited LH pulse amplitude, but not frequency, without affecting FSH pulsatility (Samuels et al. 1992). SRIF does not affect

Published by Bioscientifica Ltd. 
basal secretion of LH or FSH in cultured pituitaries from male rats (Yu et al. 1997), yet suppresses GNRH-induced LH but not FSH (Yu et al. 1997, Starcevic et al. 2002). In addition, SRIF suppressed gonadotropin levels in $60 \%$ of FSH-producing pituitary tumors and 30\% of LH-secreting pituitary adenoma cultures (Klibanski et al. 1991).

\section{TSH secretion}

Although SRIF inhibits TSH secretion, the effect is less pronounced than that of GH secretion from somatotrophs (Patel \& Srikant 1986). Both sst2 and sst5 were implicated in the suppression of TSH secretion (Shimon et al. 1997b); however, the relative contribution of individual receptor subtypes remains unknown. SRIF inhibited TRH-induced TSH secretion in normal adult males (Spoudeas et al. 1992). Similarly, SRIF suppressed TSH pulse amplitude and frequency (Samuels et al. 1992) and inhibited TSH levels in normal volunteers and in patients with primary hypothyroidism (Reichlin 1983). Octreotide and lanreotide reduced TSH secretion and normalized free thyroxine and free tri-iodothyronine levels in patients harboring pituitary TSH-secreting adenomas (Gancel et al. 1994, Beck-Peccoz \& Persani 2002). Similarly, octreotide suppressed serum TSH concentrations in nine patients harboring TSH-secreting tumors, and similarly suppressed TSH secretion in cell cultures (Bertherat et al. 1992). TSHsecreting adenomas are extremely rare, limiting the ability to comprehensively study sst receptor subtype-specific regulation of TSH secretion.

In summary, SRIF is a dominant inhibitor of both basal and induced pituitary hormone secretion. There are clear indications that sst receptor-signaling pathway activation is receptor subtype- and density-specific, as well as cell type and context specific. While GH secretion is mediated predominantly through sst2, and to a lesser extent sst5, ACTH and PRL secretion appear to be coordinated for the most part through sst5 signaling. Further study is required to delineate SRIF receptor subtype specificity and to elucidate the role of sst 1 and sst3 in pituitary hormone secretion.

\section{SRIF-independent constitutive sst receptor activity}

Constitutive receptor activity is the ability of a receptor to adopt an active conformation independently from its selective agonist (Seifert \& Wenzel-Seifert 2002). Multiple GPCRs exhibit constitutive activity in their WT form and some by acquiring naturally occurring disease-causing mutations (Seifert \& Wenzel-Seifert 2002).

Partial knockdown of sst2, sst3, or sst5 in mouse ACTH-secreting pituitary AtT-20 cells resulted in increased baseline intracellular cAMP levels and consequently ACTH secretion (Ben-Shlomo et al. 2007), while overexpression of either sst 2 or sst5 in these cells resulted in reduced cellular response $\mathrm{CRH}$ via downregulation of $\mathrm{CRH}$ receptor subtype 1 (CRH-R1) expression (Ben-Shlomo et al. 2009). In addition, moderate sst 2 overexpression in rat GH-secreting pituitary tumor cells (GC cell line) resulted in significantly decreased GH synthesis partially via GH promoter de-acetylation, which was not observed when a sst2 DRY-motif mutant lacking constitutive activity (Ben-Shlomo et al. 2013) was stably overexpressed. Inhibition of GH transcription was also observed when human pituitary cell primary cultures were infected with a low dose of sst2-containing adenovirus (Acunzo et al. 2008).

Utilizing a similar approach to study sst3 in GH-secreting cells, we show that stable sst 3 transfectants exhibited suppressed basal intracellular cAMP levels, PKA activity, and inhibition of GH transcription, though to a lesser extent as compared with sst2 overexpression. sst3-mediated GH inhibition was not regulated epigenetically but rather via dephosphorylation and thus activation of GSK3 $\beta$, a PKA substrate. The cells expressing nonconstitutively active sst3 mutated at its DRY motif were unaffected (Eigler et al. 2014).

Constitutive sst receptor activity is yet to be proven in vivo. This is challenging as a naturally occurring, disease-causing, constitutively active SSTR mutant has not yet been characterized, and an SSTR inverse agonist is not available. Moreover, the SRIF system exhibits significant redundancy, as CST and SRIF bind all sst receptor subtypes with similar affinities and the receptors also share multiple signaling pathways. To rigorously study constitutive sst2 activity in vivo will require an animal experimental model that expresses neither ligands nor all other sst receptor subtypes, a difficult task.

Evidence in the literature suggests the possible presence of constitutive sst2 activity. Intriguing evidence from mice points to conditions in which SRIF (not sst2) is dispensable for determining baseline GH control. First, abolishing SRIF-producing rat hypothalamic neurons resulted in acutely increased serum GH levels, which normalized within 10 days, without altered pituitary GH-content (Soya \& Suzuki 1990). Second, knockout Srif ${ }^{(-/-)}$, Cort ${ }^{(-/-)}$, and double-knockout Srif ${ }^{(-/-)} /$Cort $^{(-/-)}$mice do not exhibit excessive growth

Published by Bioscientifica Ltd 
(de Lecea and Castano 2006, Zeyda \& Hochgeschwender 2008, Cordoba-Chacon et al. 2011). In addition, hypersomatostatinemia elaborated by abdominal somatostatinoma tumors is not associated with GH deficiency (Oberg \& Eriksson 2005, Galli et al. 2006). Observed negative association between sst2 and GH expression support the existence of a biological relationship between the two. For example, Srif ${ }^{(-)}$mice exhibit $1.5-$ to threefold increase in GH levels along with $70 \%$ decrease in sst2 levels (Low et al. 2001, Zeyda et al. 2001). Glucocorticoids, acutely downregulate Sst2 promoter activity associated with increased pituitary GH synthesis in SRIF-free conditions (Xu et al. 1995, Zeyda et al. 2001, Kajimura et al. 2003). In contrast, adrenalectomy (cortisol deficiency) increased rat somatotroph sst2 levels (Hofland 2008). In addition, $\mathrm{E}_{2}$ lowers sst2 levels and increases baseline GH in the absence or presence of SRIF (Cardenas et al. 2003, Borghi et al. 2006, Elango et al. 2006). Aromatase-null (i.e. $\mathrm{E}_{2}$ deficient) female mice exhibited high pituitary Sst2 gene expression with concomitant low GH levels, all reversed with $\mathrm{E}_{2}$ treatment (Yan et al. 2004). Importantly, female rats exhibit continuous $\mathrm{GH}$ secretion with higher baseline levels and also have lower Sst2 expression as compared with males, while male rats treated with $\mathrm{E}_{2}$ exhibited increased baseline $\mathrm{GH}$ and downregulation of sst receptors (Baumeister \& Meyerhof 2000). In summary, when sst2 is decreased, GH is increased, with or without SRIF. Although intriguing, the physiological importance of constitutive sst receptor activity is yet unclear in vivo. As absolute receptor number in the cell also determines observed constitutive activity level, receptor expression level regulation by SRIF and other factors may control constitutive sst receptor activity.

\section{Conclusion}

SRIF system, i.e. hypothalamic SRIF14 and its cognate sst1, sst2, sst3, and sst5 receptor subtypes, control pituitary gland function, mostly inhibiting anterior pituitary gland basal and induced hormone secretion. SRIF-sst receptor signaling pathway activation is receptor subtype specific and density specific, as well as cell type and context specific. SRIF/sst2 is the main mediator of GH secretion while SRIF/sst5 mainly mediates ACTH and PRL secretion. Sst receptor activation mediates its effect through multiple pathways, mainly adenylate cyclase/cAMP/PKA, MAPK, and ion channel regulation. SRIF-independent constitutive sst receptor activity is present in pituitary cells in vitro, inhibiting cellular cAMP and ACTH responses to CRH and GH transcription.

\section{Declaration of interest}

The authors declare that there is no conflict of interest that could be perceived as prejudicing the impartiality of the review.

\section{Funding}

This review did not receive any specific grant from any funding agency in the public, commercial or not-for-profit sector.

\section{References}

Abe H, Chihara K, Minamitani N, Iwasaki J, Chiba T, Matsukura S \& Fujita T 1981 Stimulation by bombesin of immunoreactive somatostatin release into rat hypophysial portal blood. Endocrinology 109 229-234. (doi:10.1210/endo-109-1-229)

Acunzo J, Thirion S, Roche C, Saveanu A, Gunz G, Germanetti AL, Couderc B, Cohen R, Figarella-Branger D, Dufour H et al. 2008 Somatostatin receptor sst 2 decreases cell viability and hormonal hypersecretion and reverses octreotide resistance of human pituitary adenomas. Cancer Research 68 10163-10170. (doi:10.1158/0008-5472. CAN-08-1857)

Aguila MC 1998 Somatostatin decreases somatostatin messenger ribonucleic acid levels in the rat periventricular nucleus. Peptides 19 1573-1579. (doi:10.1016/S0196-9781(98)00109-0)

Baranowska B, Bik W, Baranowska-Bik A, Wolinska-Witort E, Chmielowska M \& Martynska L 2009 Cortistatin and pituitary hormone secretion in rat. Journal of Physiology and Pharmacology 60 151-156.

Bauer W, Briner U, Doepfner W, Haller R, Huguenin R, Marbach P, Petcher TJ \& Pless 1982 SMS201-995: a very potent and selective octapeptide analogue of somatostatin with prolonged action. Life Sciences 31 1133-1140. (doi:10.1016/0024-3205(82)90087-X)

Baumeister H \& Meyerhof W 2000 Gene regulation of somatostatin receptors in rats. Journal of Physiology 94 167-177. (doi:10.1016/S09284257(00)00201-1)

Beck-Peccoz P \& Persani L 2002 Medical management of thyrotropinsecreting pituitary adenomas. Pituitary 5 83-88. (doi:10.1023/ A:1022360414062)

Ben-Shlomo A \& Melmed S 2010 Pituitary somatostatin receptor signaling. Trends in Endocrinology and Metabolism 21 123-133. (doi:10.1016/j.tem. 2009.12.003)

Ben-Shlomo A, Wawrowsky KA, Proekt I, Wolkenfeld NM, Ren SG, Taylor J, Culler MD \& Melmed S 2005 Somatostatin receptor type 5 modulates somatostatin receptor type 2 regulation of adrenocorticotropin secretion. Journal of Biological Chemistry $28024011-24021$. (doi:10.1074/jbc.M501998200)

Ben-Shlomo A, Pichurin O, Barshop NJ, Wawrowsky KA, Taylor J, Culler MD, Chesnokova V, Liu NA \& Melmed S 2007 Selective regulation of somatostatin receptor subtype signaling: evidence for constitutive receptor activation. Molecular Endocrinology 21 2565-2578. (doi:10.1210/me.2007-0081)

Ben-Shlomo A, Zhou C, Pichurin O, Chesnokova V, Liu NA, Culler MD \& Melmed S 2009 Constitutive somatostatin receptor activity determines tonic pituitary cell response. Molecular Endocrinology 23 337-348. (doi:10.1210/me.2008-0361)

Ben-Shlomo A, Pichurin O, Khalafi R, Zhou C, Chesnokova V, Ren SG Liu NA \& Melmed S 2013 Constitutive somatostatin receptor subtype 2 activity attenuates GH synthesis. Endocrinology 154 2399-2409. (doi:10.1210/en.2013-1132)

Berelowitz M, Maeda K, Harris S \& Frohman LA 1980 The effect of alterations in the pituitary-thyroid axis on hypothalamic content and in vitro release of somatostatin-like immunoreactivity. Endocrinology 107 24-29. (doi:10.1210/endo-107-1-24) http://jme.endocrinology-journals.org DOI: 10.1530/JME-14-0034
C) 2014 Society for Endocrinology Printed in Great Britain 
Berelowitz M, Szabo M, Frohman LA, Firestone S, Chu L \& Hintz RL 1981 Somatomedin- $\mathrm{C}$ mediates growth hormone negative feedback by effects on both the hypothalamus and the pituitary. Science 212 1279-1281. (doi:10.1126/science.6262917)

Berelowitz M, Dudlak D \& Frohman LA 1982 Release of somatostatin-like immunoreactivity from incubated rat hypothalamus and cerebral cortex. Effects of glucose and glucoregulatory hormones. Journal of Clinical Investigation 69 1293-1301. (doi:10.1172/JCI110569)

Berelowitz M, Xu Y, Song J \& Bruno JF 1995 Regulation of somatostatin receptor mRNA expression. Ciba Foundation Symposium 190 111-122; discussion 122-116.

Bertherat J, Brue T, Enjalbert A, Gunz G, Rasolonjanahary R, Warnet A Jaquet P \& Epelbaum J 1992 Somatostatin receptors on thyrotropinsecreting pituitary adenomas: comparison with the inhibitory effects of octreotide upon in vivo and in vitro hormonal secretions. Journal of Clinical Endocrinology and Metabolism 75 540-546. (doi:10.1210/jcem. 75.2.1353505)

Bichet DG 2011 The Posterior pituitary. In Pituitary, pp 261-299. Ed S Melmed. San Diego, California: Elsevier.

Bilezikjian LM \& Vale WW 1983 Stimulation of adenosine $3^{\prime}, 5^{\prime}$-monophosphate production by growth hormone-releasing factor and its inhibition by somatostatin in anterior pituitary cells in vitro. Endocrinology 113 1726-1731. (doi:10.1210/endo-113-5-1726)

Bjoro T, Ostberg BC, Sand O, Gordeladze J, Iversen JG, Torjesen PA, Gautvik KM \& Haug E 1987 Vasoactive intestinal peptide and peptide with $\mathrm{N}$-terminal histidine and $\mathrm{C}$-terminal isoleucine increase prolactin secretion in cultured rat pituitary cells (GH4C1) via a cAMP-dependent mechanism which involves transient elevation of intracellular $\mathrm{Ca}^{2+}$ Molecular and Cellular Endocrinology 49 119-128. (doi:10.1016/03037207(87)90205-X)

Bocca L, Valenti S, Cuttica CM, Spaziante R, Giordano G \& Giusti M 2000 Nitric oxide biphasically modulates GH secretion in cultured cells of GH-secreting human pituitary adenomas. Minerva Endocrinologica 25 55-59.

Bonnefont X, Fiekers J, Creff A \& Mollard P 2000 Rhythmic bursts of calcium transients in acute anterior pituitary slices. Endocrinology 141 868-875. (doi:10.1210/endo.141.3.7363)

Borghi MM, Longui CA, Calliari LE, Faria CD, Kochi C \& Monte O 2006 Transdermal estradiol priming during clonidine stimulation test in non-growth hormone deficient children with short stature: a pilot study. Journal of Pediatric Endocrinology \& Metabolism 19 223-227. (doi:10.1515/JPEM.2006.19.3.223)

Broglio F, Arvat E, Benso A, Gottero C, Prodam F, Grottoli S, Papotti M, Muccioli G, van der Lely AJ, Deghenghi R et al. 2002 Endocrine activities of cortistatin-14 and its interaction with GHRH and ghrelin in humans. Journal of Clinical Endocrinology and Metabolism 87 3783-3790. (doi:10.1210/jcem.87.8.8749)

Brown MR, Rivier C \& Vale W 1984 Central nervous system regulation of adrenocorticotropin secretion: role of somatostatins. Endocrinology $\mathbf{1 1 4}$ 1546-1549. (doi:10.1210/endo-114-5-1546)

Bruns C, Lewis I, Briner U, Meno-Tetang G \& Weckbecker G 2002 SOM230: a novel somatostatin peptidomimetic with broad somatotropin release inhibiting factor (SRIF) receptor binding and a unique antisecretory profile. European Journal of Endocrinology 146 707-716. (doi:10.1530/ eje.0.1460707)

Burgus R, Ling N, Butcher M \& Guillemin R 1973 Primary structure of somatostatin, a hypothalamic peptide that inhibits the secretion of pituitary growth hormone. PNAS 70684-688. (doi:10.1073/pnas.70.3.684)

Canosa LF, Lin X \& Peter RE 2003 Effects of sex steroid hormones on the expression of somatostatin receptors sst 1 and sst 5 in goldfish pituitary and forebrain. Neuroendocrinology 78 81-89. (doi:10.1159/000071963)

Cardenas R, Lin X, Canosa LF, Luna M, Aramburo C \& Peter RE 2003 Estradiol reduces pituitary responsiveness to somatostatin (SRIF-14) and down-regulates the expression of somatostatin sst2 receptors in female goldfish pituitary. General and Comparative Endocrinology 132 119-124. (doi:10.1016/S0016-6480(03)00055-8)
Cerovac V, Monteserin-Garcia J, Rubinfeld H, Buchfelder M, Losa M Florio T, Paez-Pereda M, Stalla GK \& Theodoropoulou M 2010 The somatostatin analogue octreotide confers sensitivity to rapamycin treatment on pituitary tumor cells. Cancer Research 70 666-674. (doi:10.1158/0008-5472.CAN-09-2951)

Cervia D 2011 The beta isoenzyme of $\mathrm{Ca}(2+) /$ calmodulin-dependent kinase type II as possible mediator of somatostatin functions in pituitary tumour cells. General Physiology and Biophysics 30 251-262. (doi:10.4149/gpb_2011_03_251)

Cervia D \& Bagnoli P 2007 An update on somatostatin receptor signaling in native systems and new insights on their pathophysiology. Pharmacology \& Therapeutics 116 322-341. (doi:10.1016/j.pharmthera. 2007.06.010)

Cervia D, Petrucci C, Bluet-Pajot MT, Epelbaum J \& Bagnoli P $2002 a$ Inhibitory control of growth hormone secretion by somatostatin in rat pituitary GC cells: sst(2) but not sst(1) receptors are coupled to inhibition of single-cell intracellular free calcium concentrations. Neuroendocrinology 76 99-110. (doi:10.1159/000064424)

Cervia D, Fiorini S, Pavan B, Biondi C \& Bagnoli P 2002b Somatostatin (SRIF) modulates distinct signaling pathways in rat pituitary tumor cells; negative coupling of SRIF receptor subtypes 1 and 2 to arachidonic acid release. Naunyn-Schmiedeberg's Archives of Pharmacology 365 200-209. (doi:10.1007/s00210-001-0509-7)

Cervia D, Zizzari P, Pavan B, Schuepbach E, Langenegger D, Hoyer D, Biondi C, Epelbaum J \& Bagnoli P 2003 Biological activity of somatostatin receptors in GC rat tumour somatotrophs: evidence with sst1-sst5 receptor-selective nonpeptidyl agonists. Neuropharmacology 44 672-685. (doi:10.1016/S0028-3908(03)00031-5)

Chen C $1997 \mathrm{G}(\mathrm{o}) 2$ and $\mathrm{Gi} 3$ proteins mediate the action of somatostatin on membrane $\mathrm{Ca}^{2+}$ and $\mathrm{K}^{+}$currents in ovine pituitary somatotrophs. Clinical and Experimental Pharmacology \& Physiology 24 639-645. (doi:10.1111/j.1440-1681.1997.tb02105.x)

Chen C, Zhang J, Vincent JD \& Israel JM 1990 Somatostatin increases voltage-dependent potassium currents in rat somatotrophs. American Journal of Physiology 259 C854-C861.

Colao A, Pivonello R, Di Somma C, Savastano S, Grasso LF \& Lombardi G 2009 Medical therapy of pituitary adenomas: effects on tumor shrinkage. Reviews in Endocrine \& Metabolic Disorders 10 111-123. (doi:10.1007/s11154-008-9107-z)

Colao A, Petersenn S, Newell-Price J, Findling JW, Gu F, Maldonado M, Schoenherr U, Mills D, Salgado LR, Biller BM et al. 2012 A 12-month phase 3 study of pasireotide in Cushing's disease. New England Journal of Medicine 366 914-924. (doi:10.1056/NEJMoa1105743)

Colao A, Bronstein M, Freda P, Gu F, Shen CC, Gadelha M, Fleseriu M, van der Lely A, Farrall A, Hermosillo Resendiz K et al. 2014 Pasireotide versus octreotide in acromegaly: a head-to-head superiority study. Journal of Clinical Endocrinology and Metabolism.

Cordoba-Chacon J, Gahete MD, Pozo-Salas AI, Martinez-Fuentes AJ, de Lecea L, Gracia-Navarro F, Kineman RD, Castano JP \& Luque RM 2011 Cortistatin is not a somatostatin analogue but stimulates prolactin release and inhibits GH and ACTH in a gender-dependent fashion: potential role of ghrelin. Endocrinology 152 4800-4812. (doi:10.1210/en.2011-1542)

Cordoba-Chacon J, Gahete MD, Culler MD, Castano JP, Kineman RD \& Luque RM 2012 Somatostatin dramatically stimulates growth hormone release from primate somatotrophs acting at low doses via somatostatin receptor 5 and cyclic AMP. Journal of Neuroendocrinology 24 453-463. (doi:10.1111/j.1365-2826.2011.02261.x)

Davis JR, Wilson EM, Vidal ME, Johnson AP, Lynch SS \& Sheppard MC 1989 Regulation of growth hormone secretion and messenger ribonucleic acid accumulation in human somatotropinoma cells in vitro. Journal of Clinical Endocrinology and Metabolism 69 704-708. (doi:10.1210/jcem-69-4-704)

Degtiar VE, Harhammer R \& Nurnberg B 1997 Receptors couple to L-type calcium channels via distinct Go proteins in rat neuroendocrine cell 
lines. Journal of Physiology 502 321-333. (doi:10.1111/j.1469-7793. 1997.321bk.x)

Djordjijevic D, Zhang J, Priam M, Viollet C, Gourdji D, Kordon C \& Epelbaum J 1998 Effect of $17 \beta$-estradiol on somatostatin receptor expression and inhibitory effects on growth hormone and prolactin release in rat pituitary cell cultures. Endocrinology 139 2272-2277. (doi:10.1210/endo.139.5.5990)

Donoghue DJ \& Scanes CG 1991 Possible involvement of adenylyl cyclasecAMP-protein kinase a pathway in somatostatin inhibition of growth hormone release from chicken pituitary cells. General and Comparative Endocrinology 81 113-119. (doi:10.1016/0016-6480(91)90131-O)

Draznin B, Dahl R, Sherman N, Sussman KE \& Staehelin LA 1988 Exocytosis in normal anterior pituitary cells. Quantitative correlation between growth hormone release and the morphological features of exocytosis. Journal of Clinical Investigation 81 1042-1050. (doi:10.1172/JCI113415)

Drouin J 2011 Pituitary development. In Pituitary, 3rd edn, pp 3-19. Ed S Melmed. San Diego, California: Elsevier.

Eigler T, Ben-Shlomo A, Zhou C, Khalafi R, Ren SG \& Melmed S 2014 Constitutive somatostatin receptor subtype-3 signaling suppresses growth hormone synthesis. Molecular Endocrinology 28 554-564. (doi:10.1210/me.2013-1327)

Elango A, Shepherd B \& Chen TT 2006 Effects of endocrine disrupters on the expression of growth hormone and prolactin mRNA in the rainbow trout pituitary. General and Comparative Endocrinology 145 116-127. (doi:10.1016/j.ygcen.2005.08.003)

Estupina C, Belmar J, Tapia-Arancibia L, Astier H \& Arancibia S 1997 Rapid and opposite effects of dexamethasone on in vivo and in vitro hypothalamic somatostatin release. Experimental Brain Research $\mathbf{1 1 3}$ 337-342. (doi:10.1007/BF02450331)

Farhy LS \& Veldhuis JD 2004 Putative GH pulse renewal: periventricular somatostatinergic control of an arcuate-nuclear somatostatin and GH-releasing hormone oscillator. American Journal of Physiology. Regulatory, Integrative and Comparative Physiology 286 R1030-R1042. (doi:10.1152/ajpregu.00473.2003)

Fehm HL, Voigt KH, Lang R, Beinert KE, Raptis S \& Pfeiffer EF 1976 Somatostatin: a potent inhibitor of ACTH-hypersecretion in adrenal insufficiency. Klinische Wochenschrift 54 173-175. (doi:10.1007/ BF01468882)

Fernandez G, Sanchez-Franco F, de los Frailes MT, Tolon RM, Lorenzo MJ, Lopez J \& Cacicedo L 1992 Regulation of somatostatin and growth hormone-releasing factor by gonadal steroids in fetal rat hypothalamic cells in culture. Regulatory Peptides 42 135-144. (doi:10.1016/0167. 0115(92)90093-A)

Ferrante E, Pellegrini C, Bondioni S, Peverelli E, Locatelli M, Gelmini P, Luciani P, Peri A, Mantovani G, Bosari S et al. 2006 Octreotide promotes apoptosis in human somatotroph tumor cells by activating somatostatin receptor type 2. Endocrine-Related Cancer 13 955-962. (doi:10.1677/erc.1.01191)

Florio T 2008 Somatostatin/somatostatin receptor signalling: phosphotyrosine phosphatases. Molecular and Cellular Endocrinology 286 40-48. (doi:10.1016/j.mce.2007.08.012)

Florio T, Thellung S, Arena S, Corsaro A, Spaziante R, Gussoni G, Acuto G, Giusti M, Giordano G \& Schettini G 1999 Somatostatin and its analog lanreotide inhibit the proliferation of dispersed human non-functioning pituitary adenoma cells in vitro. European Journal of Endocrinology 141 396-408. (doi:10.1530/eje.0.1410396)

Florio T, Thellung S, Corsaro A, Bocca L, Arena S, Pattarozzi A, Villa V, Massa A, Diana F, Schettini D et al. 2003 Characterization of the intracellular mechanisms mediating somatostatin and lanreotide inhibition of DNA synthesis and growth hormone release from dispersed human GH-secreting pituitary adenoma cells in vitro. Clinical Endocrinology 59 115-128. (doi:10.1046/j.1365-2265.2003.01811.x)

Foster GA \& Johansson O 1985 Ultrastructural morphometric analysis of somatostatin-like immunoreactive neurones in the rat central nervous system after labelling with colloidal gold. Brain Research 342 117-127. (doi:10.1016/0006-8993(85)91359-9)
Fusco A, Gunz G, Jaquet P, Dufour H, Germanetti AL, Culler MD, Barlier A \& Saveanu A 2008 Somatostatinergic ligands in dopamine-sensitive and -resistant prolactinomas. European Journal of Endocrinology 158 595-603. (doi:10.1530/EJE-07-0806)

Galanopoulou AS, Seidah NG \& Patel YC 1995 Heterologous processing of rat prosomatostatin to somatostatin-14 by PC2: requirement for secretory cell but not the secretion granule. Biochemical Journal $\mathbf{3 1 1}$ 111-118.

Galli G, Zonefrati R, Gozzini A, Mavilia C, Martineti V, Tognarini I, Nesi G, Marcucci T, Tonelli F, Tommasi M et al. 2006 Characterization of the functional and growth properties of long-term cell cultures established from a human somatostatinoma. Endocrine-Related Cancer 13 79-93. (doi:10.1677/erc.1.00988)

Gancel A, Vuillermet P, Legrand A, Catus F, Thomas F \& Kuhn JM 1994 Effects of a slow-release formulation of the new somatostatin analogue lanreotide in TSH-secreting pituitary adenomas. Clinical Endocrinology 40 421-428. (doi:10.1111/j.1365-2265.1994.tb03941.x)

Giustina A \& Veldhuis JD 1998 Pathophysiology of the neuroregulation of growth hormone secretion in experimental animals and the human. Endocrine Reviews 19 717-797. (doi:10.1210/edrv.19.6.0353)

Gooren LJ, Harmsen-Louman W \& van Kessel H 1984 Somatostatin inhibits prolactin release from the lactotroph primed with oestrogen and cyproterone acetate in man. Journal of Endocrinology 103 333-335. (doi:10.1677/joe.0.1030333)

Goth MI, Lyons CE Jr, Ellwood MR, Barrett JR \& Thorner MO 1996 Chronic estrogen treatment in male rats reveals mammosomatotropes and allows inhibition of prolactin secretion by somatostatin. Endocrinology 137 274-280. (doi:10.1210/endo.137.1.8536623)

Grant M, Alturaihi H, Jaquet P, Collier B \& Kumar U 2008 Cell growth inhibition and functioning of human somatostatin receptor type 2 are modulated by receptor heterodimerization. Molecular Endocrinology 22 2278-2292. (doi:10.1210/me.2007-0334)

Greenman Y \& Stern N 2009 Non-functioning pituitary adenomas. Best Practice \& Research. Clinical Endocrinology \& Metabolism 23 625-638. (doi:10.1016/j.beem.2009.05.005)

Gruszka A, Ren SG, Dong J, Culler MD \& Melmed S 2007 Regulation of growth hormone and prolactin gene expression and secretion by chimeric somatostatin-dopamine molecules. Endocrinology 148 6107-6114. (doi:10.1210/en.2007-0378)

Gruszka A, Culler MD \& Melmed S 2012 Somatostatin analogs and chimeric somatostatin-dopamine molecules differentially regulate human growth hormone and prolactin gene expression and secretion in vitro. Molecular and Cellular Endocrinology 362 104-109. (doi:10.1016/j.mce. 2012.05.020)

Guillermet-Guibert J, Saint-Laurent N, Davenne L, Rochaix P, Cuvillier O, Culler MD, Pradayrol L, Buscail L, Susini C \& Bousquet C 2007 Novel synergistic mechanism for sst2 somatostatin and TNF $\alpha$ receptors to induce apoptosis: crosstalk between NF-kB and JNK pathways. Cell Death and Differentiation 14 197-208. (doi:10.1038/sj.cdd.4401939)

Hao L, Li M, Dai J, Wu Q, Liu Y, Liu S \& Zhang Y 2010 Reduced somatostatin in hypothalamus of young male mouse increases local but not circulatory GH. Neurochemical Research 35 143-151. (doi:10.1007/ s11064-009-0039-0)

Hassan HA, Enright WJ, Tucker HA \& Merkel RA 2001 Estrogen and androgen elicit growth hormone release via dissimilar patterns of hypothalamic neuropeptide secretion. Steroids 66 71-80. (doi:10.1016/ S0039-128X(00)00168-9)

Heisler S, Reisine TD, Hook VY \& Axelrod J 1982 Somatostatin inhibits multireceptor stimulation of cyclic AMP formation and corticotropin secretion in mouse pituitary tumor cells. PNAS 79 6502-6506. (doi:10.1073/pnas.79.21.6502)

Hipkin RW, Friedman J, Clark RB, Eppler CM \& Schonbrunn A 1997 Agonist-induced desensitization, internalization, and phosphorylation of the sst2A somatostatin receptor. Journal of Biological Chemistry 272 13869-13876. (doi:10.1074/jbc.272.21.13869) 
van der Hoek J, Waaijers M, van Koetsveld PM, Sprij-Mooij D, Feelders RA, Schmid HA, Schoeffter P, Hoyer D, Cervia D, Taylor JE et al. 2005 Distinct functional properties of native somatostatin receptor subtype 5 compared with subtype 2 in the regulation of ACTH release by corticotroph tumor cells. American Journal of Physiology. Endocrinology and Metabolism 289 (Suppl 1) E278-E287. (doi:10.1152/ajpendo.00004. 2005)

van der Hoek J, Lamberts SW \& Hofland LJ 2007 Preclinical and clinical experiences with the role of somatostatin receptors in the treatment of pituitary adenomas. European Journal of Endocrinology 156 S45-S51. (doi:10.1530/eje.1.02350)

Hofland LJ 2008 Somatostatin and somatostatin receptors in Cushing's disease. Molecular and Cellular Endocrinology 286 199-205. (doi:10.1016/ j.mce.2007.10.015)

Hofland LJ, van der Hoek J, van Koetsveld PM, de Herder WW, Waaijers M, Sprij-Mooij D, Bruns C, Weckbecker G, Feelders R, van der Lely AJ et al. 2004 The novel somatostatin analog SOM230 is a potent inhibitor of hormone release by growth hormone- and prolactin-secreting pituitary adenomas in vitro. Journal of Clinical Endocrinology and Metabolism 89 1577-1585. (doi:10.1210/jc.2003-031344)

Holl RW, Thorner MO, Mandell GL, Sullivan JA, Sinha YN \& Leong DA 1988 Spontaneous oscillations of intracellular calcium and growth hormone secretion. Journal of Biological Chemistry 263 9682-9685.

Honegger J, Spagnoli A, D’Urso R, Navarra P, Tsagarakis S, Besser GM \& Grossman AB 1991 Interleukin-1 beta modulates the acute release of growth hormone-releasing hormone and somatostatin from rat hypothalamus in vitro, whereas tumor necrosis factor and interleukin-6 have no effect. Endocrinology 129 1275-1282. (doi:10.1210/endo-129-31275)

Horiguchi K, Yamada M, Satoh T, Hashimoto K, Hirato J, Tosaka M, Yamada S \& Mori M 2009 Transcriptional activation of the mixed lineage leukemia-p27Kip1 pathway by a somatostatin analogue. Clinical Cancer Research 15 2620-2629. (doi:10.1158/1078-0432.CCR08-2473)

Hubina E, Nanzer AM, Hanson MR, Ciccarelli E, Losa M, Gaia D, Papotti M, Terreni MR, Khalaf S, Jordan S et al. 2006 Somatostatin analogues stimulate p27 expression and inhibit the MAP kinase pathway in pituitary tumours. European Journal of Endocrinology 155 371-379. (doi:10.1530/eje.1.02213)

Ikuyama S, Nawata H, Kato K, Natori S \& Ibayashi H 1987 Phorbol ester and phospholipase C-induced growth hormone secretion from pituitary somatotroph adenoma cells in culture: effects of somatostatin, bromocriptine, and pertussis toxin. Journal of Clinical Endocrinology and Metabolism 64 572-577. (doi:10.1210/jcem-64-3-572)

Iwasaki K, Fujii A, Merchenthaler I, Groot K \& Arimura A 1987 The stimulation of somatostatin release by hpGRF44 from rat hypothalamic cells and fragments in vitro. Tokai Journal of Experimental and Clinical Medicine 12 117-124.

James RA, Sarapura VD, Bruns C, Raulf F, Dowding JM, Gordon DF, Wood WM \& Ridgway EC 1997 Thyroid hormone-induced expression of specific somatostatin receptor subtypes correlates with involution of the TtT-97 murine thyrotrope tumor. Endocrinology 138 719-724. (doi:10.1210/endo.138.2.4951)

Jaquet P, Ouafik L, Saveanu A, Gunz G, Fina F, Dufour H, Culler MD, Moreau JP \& Enjalbert A 1999 Quantitative and functional expression of somatostatin receptor subtypes in human prolactinomas. Journal of Clinical Endocrinology and Metabolism 84 3268-3276. (doi:10.1210/ jcem.84.9.5962)

Judd AM, Koike K \& MacLeod RM 1986 A possible role of arachidonate metabolism in the mechanism of prolactin release. American Journal of Physiology 250 E288-E295.

Kajimura S, Hirano T, Visitacion N, Moriyama S, Aida K \& Grau EG 2003 Dual mode of cortisol action on GH/IGF-I/IGF binding proteins in the tilapia, Oreochromis mossambicus. Journal of Endocrinology 178 91-99. (doi:10.1677/joe.0.1780091)
Karanth S, Aguila MC \& McCann SM 1993 The influence of interleukin-2 on the release of somatostatin and growth hormone-releasing hormone by mediobasal hypothalamus. Neuroendocrinology 58 185-190.

Kawano H \& Daikoku S 1988 Somatostatin-containing neuron systems in the rat hypothalamus: retrograde tracing and immunohistochemical studies. Journal of Comparative Neurology 271 293-299. (doi:10.1002/ cne.902710209)

Khattak MN, Buchfelder M, Kleindienst A, Schofl C \& Kremenevskaja N 2010 CRH and SRIF have opposite effects on the Wnt/ $\beta$-catenin signalling pathway through PKA/GSK-3 $\beta$ in corticotroph pituitary cells. Cancer Investigation 28 797-805. (doi:10.3109/07357907.2010.494318)

Kimura N, Tomizawa S \& Arai KN 1998 Chronic treatment with estrogen up-regulates expression of sst2 messenger ribonucleic acid (mRNA) but down-regulates expression of sst5 mRNA in rat pituitaries. Endocrinology 139 1573-1580. (doi:10.1210/endo.139.4.5952)

Kleuss C, Scherubl H, Hescheler J, Schultz G \& Wittig B 1992 Different beta-subunits determine G-protein interaction with transmembrane receptors. Nature 358 424-426. (doi:10.1038/358424a0)

Kleuss C, Scherubl H, Hescheler J, Schultz G \& Wittig B 1993 Selectivity in signal transduction determined by gamma subunits of heterotrimeric $\mathrm{G}$ proteins. Science 259 832-834. (doi:10.1126/science.8094261)

Klibanski A, Alexander JM, Bikkal HA, Hsu DW, Swearingen B \& Zervas NT 1991 Somatostatin regulation of glycoprotein hormone and free subunit secretion in clinically nonfunctioning and somatotroph adenomas in vitro. Journal of Clinical Endocrinology and Metabolism $\mathbf{7 3}$ 1248-1255. (doi:10.1210/jcem-73-6-1248)

Koch BD, Dorflinger LJ \& Schonbrunn A 1985 Pertussis toxin blocks both cyclic AMP-mediated and cyclic AMP-independent actions of somatostatin. Evidence for coupling of $\mathrm{Ni}$ to decreases in intracellular free calcium. Journal of Biological Chemistry 260 13138-13145.

Korbonits M, Little JA, Forsling ML, Tringali G, Costa A, Navarra P, Trainer PJ \& Grossman AB 1999 The effect of growth hormone secretagogues and neuropeptide $\mathrm{Y}$ on hypothalamic hormone release from acute rat hypothalamic explants. Journal of Neuroendocrinology 11 521-528. (doi:10.1046/j.1365-2826.1999.00353.x)

Kraicer J \& Spence JW 1981 Release of growth hormone from purified somatotrophs: use of high $\mathrm{K}^{+}$and the ionophore A23187 to elucidate interrelations among $\mathrm{Ca}^{++}$, adenosine $3^{\prime}, 5^{\prime}$-monophosphate, and somatostatin. Endocrinology 108 651-657. (doi:10.1210/endo-108-2-651)

Kraicer J, Gajewski TC \& Moor BC 1985 Release of pro-opiomelanocortinderived peptides from the pars intermedia and pars distalis of the rat pituitary: effect of corticotrophin-releasing factor and somatostatin. Neuroendocrinology 41 363-373. (doi:10.1159/000124203)

Lamberts SW, Zuyderwijk J, den Holder F, van Koetsveld P \& Hofland L $1989 a$ Studies on the conditions determining the inhibitory effect of somatostatin on adrenocorticotropin, prolactin and thyrotropin release by cultured rat pituitary cells. Neuroendocrinology 50 44-50. (doi:10.1159/000125200)

Lamberts SW, Uitterlinden P \& Klijn JM $1989 b$ The effect of the long-acting somatostatin analogue SMS 201-995 on ACTH secretion in Nelson's syndrome and Cushing's disease. Acta Endocrinologica 120 760-766.

de Lecea L \& Castano JP 2006 Cortistatin: not just another somatostatin analog. Nature Clinical Practice. Endocrinology \& Metabolism 2 356-357. (doi:10.1038/ncpendmet0219)

Lee SC \& Shin SH 1996 Somatostatin does not inhibit prolactin synthesis in normal male rat pituitary cells but inhibits prolactin synthesis in estradiol-primed pituitary cells. Journal of Endocrinology 148 69-76. (doi:10.1677/joe.0.1480069)

Lengyel AM, Grossman A, Bouloux PM, Rees LH \& Besser GM 1985 Effects of dopamine and morphine on immunoreactive somatostatin and LHreleasing hormone secretion from hypothalamic fragments in vitro. Journal of Endocrinology 106 317-322. (doi:10.1677/joe.0.1060317)

Liu YF, Jakobs KH, Rasenick MM \& Albert PR 1994 G protein specificity in receptor-effector coupling. Analysis of the roles of G0 and Gi2 in GH4C1 pituitary cells. Journal of Biological Chemistry 269 13880-13886.

Published by Bioscientifica Ltd. 
Liu HS, Hu ZT, Zhou KM, Jiu YM, Yang H, Wu ZX \& Xu T 2006 Heterogeneity of the $\mathrm{Ca}^{2+}$ sensitivity of secretion in a pituitary gonadotrope cell line and its modulation by protein kinase $\mathrm{C}$ and $\mathrm{Ca}^{2+}$. Journal of Cellular Physiology 207 668-674. (doi:10.1002/jcp.20598)

Liu Q, Bee MS \& Schonbrunn A 2009 Site specificity of agonist and second messenger-activated kinases for somatostatin receptor subtype $2 \mathrm{~A}$ (Sst2A) phosphorylation. Molecular Pharmacology 76 68-80. (doi:10.1124/mol.108.054262)

Lohrer P, Gloddek J, Hopfner U, Losa M, Uhl E, Pagotto U, Stalla GK \& Renner U 2001 Vascular endothelial growth factor production and regulation in rodent and human pituitary tumor cells in vitro. Neuroendocrinology 74 95-105. (doi:10.1159/000054675)

Low MJ, Otero-Corchon V, Parlow AF, Ramirez JL, Kumar U, Patel YC \& Rubinstein M 2001 Somatostatin is required for masculinization of growth hormone-regulated hepatic gene expression but not of somatic growth. Journal of Clinical Investigation 107 1571-1580. (doi:10.1172/ JCI11941)

Luque RM, Park S, Peng XD, Delgado E, Gracia-Navarro F, Kineman RD, Malagon MM \& Castano JP 2004 Homologous and heterologous in vitro regulation of pig pituitary somatostatin receptor subtypes, sst1, sst2 and sst5 mRNA. Journal of Molecular Endocrinology 32 437-448. (doi:10. 1677/jme.0.0320437)

Luque RM, Rodriguez-Pacheco F, Tena-Sempere M, Gracia-Navarro F, Malagon MM \& Castano JP 2005 Differential contribution of nitric oxide and cGMP to the stimulatory effects of growth hormonereleasing hormone and low-concentration somatostatin on growth hormone release from somatotrophs. Journal of Neuroendocrinology $\mathbf{1 7}$ 577-582. (doi:10.1111/j.1365-2826.2005.01345.x)

Luque RM, Duran-Prado M, Garcia-Navarro S, Gracia-Navarro F, Kineman RD, Malagon MM \& Castano JP 2006a Identification of the somatostatin receptor subtypes (sst) mediating the divergent, stimulatory/inhibitory actions of somatostatin on growth hormone secretion. Endocrinology 147 2902-2908. (doi:10.1210/en. 2005-1559)

Luque RM, Gahete MD, Hochgeschwender U \& Kineman RD 2006b Evidence that endogenous SST inhibits ACTH and ghrelin expression by independent pathways. American Journal of Physiology. Endocrinology and Metabolism 291 E395-E403. (doi:10.1152/ajpendo. 00038.2006)

Maeda K \& Frohman LA 1980 Release of somatostatin and thyrotropinreleasing hormone from rat hypothalamic fragments in vitro. Endocrinology 106 1837-1842. (doi:10.1210/endo-106-6-1837)

Matsuno A, Itoh J, Takekoshi S, Itoh Y, Ohsugi Y, Katayama H, Nagashima T \& Osamura RY 2003 Dynamics of subcellular organelles, growth hormone, Rab3B, SNAP-25, and syntaxin in rat pituitary cells caused by growth hormone releasing hormone and somatostatin. Microscopy Research and Technique 62 232-239. (doi:10.1002/jemt. 10364)

Melmed S 2006 Medical progress: acromegaly. New England Journal of Medicine 355 2558-2573. (doi:10.1056/NEJMra062453)

Millar RP, Klaff LJ, Barron J, Levitt NS \& Ling N 1982 Somatostatin-28 inhibits LHRH-stimulated gonadotrophin secretion in man. Clinical Endocrinology 17 103-107. (doi:10.1111/j.1365-2265.1982.tb01569.x)

Morishita M, Iwasaki Y, Onishi A, Asai M, Mutsuga N, Yoshida M, Oiso Y, Inoue K \& Murohara T 2003 The effects of GH-releasing hormone/ somatostatin on the $5^{\prime}$-promoter activity of the GH gene in vitro. Journal of Molecular Endocrinology 31 441-448. (doi:10.1677/jme.0. 0310441)

Namba H, Morita S \& Melmed S 1989 Insulin-like growth factor-I action on growth hormone secretion and messenger ribonucleic acid levels: interaction with somatostatin. Endocrinology 124 1794-1799. (doi:10.1210/endo-124-4-1794)

Negro-Vilar A, Ojeda SR, Arimura A \& McCann SM 1978 Dopamine and norepinephrine stimulate somatostatin release by median eminence fragments in vitro. Life Sciences 23 1493-1497.
Norman M, Moldovan S, Seghers V, Wang XP, DeMayo FJ \& Brunicardi FC 2002 Sulfonylurea receptor knockout causes glucose intolerance in mice that is not alleviated by concomitant somatostatin subtype receptor 5 knockout. Annals of Surgery 235 767-774. (doi:10.1097/ 00000658-200206000-00003)

Oberg K \& Eriksson B 2005 Endocrine tumours of the pancreas. Best Practice \& Research. Clinical Gastroenterology 19 753-781. (doi:10.1016/j.bpg. 2005.06.002)

Otsuka F, Tsukamoto N, Miyoshi T, Iwasaki Y \& Makino H 2012 BMP action in the pituitary: its possible role in modulating somatostatin sensitivity in pituitary tumor cells. Molecular and Cellular Endocrinology 349 105-110. (doi:10.1016/j.mce.2011.10.017)

Panetta R \& Patel YC 1995 Expression of mRNA for all five human somatostatin receptors (hSSTR1-5) in pituitary tumors. Life Sciences $\mathbf{5 6}$ 333-342. (doi:10.1016/0024-3205(94)00956-2)

Park C, Yang I, Woo J, Kim S, Kim J, Kim Y, Sohn S, Kim E, Lee M, Park H et al. 2004 Somatostatin (SRIF) receptor subtype 2 and 5 gene expression in growth hormone-secreting pituitary adenomas: the relationship with endogenous srif activity and response to octreotide. Endocrine Journal 51 227-236. (doi:10.1507/endocrj.51.227)

van der Pas R, Feelders RA, Gatto F, de Bruin C, Pereira AM, van Koetsveld PM, Sprij-Mooij DM, Waaijers AM, Dogan F, Schulz S et al. 2013 Preoperative normalization of cortisol levels in Cushing's disease after medical treatment: consequences for somatostatin and dopamine receptor subtype expression and in vitro response to somatostatin analogs and dopamine agonists. Journal of Clinical Endocrinology and Metabolism 98 E1880-E1890. (doi:10.1210/jc.2013-1987)

Patel YC, Greenwood M, Kent G, Panetta R \& Srikant CB 1993 Multiple gene transcripts of the somatostatin receptor SSTR2: tissue selective distribution and CAMP regulation. Biochemical and Biophysical Research Communications 192 288-294. (doi:10.1006/bbrc.1993.1412)

Patel YC 1999 Somatostatin and its receptor family. Frontiers in Neuroendocrinology 20 157-198. (doi:10.1006/frne.1999.0183)

Patel YC \& Srikant CB 1986 Somatostatin mediation of adenohypophysial secretion. Annual Review of Physiology 48 551-567. (doi:10.1146/ annurev.ph.48.030186.003003)

Peterfreund RA \& Vale WW 1983 Muscarinic cholinergic stimulation of somatostatin secretion from long term dispersed cell cultures of fetal rat hypothalamus: inhibition by gamma-aminobutyric acid and serotonin. Endocrinology 112 526-534. (doi:10.1210/endo-112-2-526)

Petersenn S, Rasch AC, Presch S, Beil FU \& Schulte HM 1999 Genomic structure and transcriptional regulation of the human somatostatin receptor type 2. Molecular and Cellular Endocrinology 157 75-85. (doi:10. 1016/S0303-7207(99)00161-6)

Petersenn S, Farrall AJ, Block C, Melmed S, Schopohl J, Caron P, Cuneo R, Kleinberg D, Colao A, Ruffin M et al. 2014a Long-term efficacy and safety of subcutaneous pasireotide in acromegaly: results from an openended, multicenter, phase II extension study. Pituitary 17 132-140. (doi:10.1007/s11102-013-0478-0)

Petersenn S, Farrall AJ, De Block C, Melmed S, Schopohl J, Caron P, Cuneo R, Kleinberg D, Colao A, Ruffin M et al. 2014b Erratum to: Long-term efficacy and safety of subcutaneous pasireotide in acromegaly: results from an open-ended, multicenter, phase II extension study. Pituitary 17 141. (doi:10.1007/s11102-013-0491-3)

Petrucci C, Cervia D, Buzzi M, Biondi C \& Bagnoli P 2000 Somatostatininduced control of cytosolic free calcium in pituitary tumour cells. British Journal of Pharmacology 129 471-484. (doi:10.1038/sj.bjp. 0703075)

Peverelli E, Mantovani G, Calebiro D, Doni A, Bondioni S, Lania A, Beck-Peccoz P \& Spada A 2008 The third intracellular loop of the human somatostatin receptor 5 is crucial for arrestin binding and receptor internalization after somatostatin stimulation. Molecular Endocrinology 22 676-688. (doi:10.1210/me.2007-0068)

Peverelli E, Busnelli M, Vitali E, Giardino E, Gales C, Lania AG, Beck-Peccoz P, Chini B, Mantovani G \& Spada A 2013 Specific roles of G(i) protein family members revealed by dissecting SST5 coupling in 
human pituitary cells. Journal of Cell Science 126 638-644. (doi:10.1242/ jcs.116434)

Pfeiffer M, Koch T, Schroder H, Laugsch M, Hollt V \& Schulz S 2002 Heterodimerization of somatostatin and opioid receptors crossmodulates phosphorylation, internalization, and desensitization. Journal of Biological Chemistry 277 19762-19772. (doi:10.1074/jbc. M110373200)

Pillon D, Caraty A, Fabre-Nys C, Lomet D, Cateau M \& Bruneau G 2004 Regulation by estradiol of hypothalamic somatostatin gene expression: possible involvement of somatostatin in the control of luteinizing hormone secretion in the ewe. Biology of Reproduction 71 38-44. (doi:10. 1095/biolreprod.103.023689)

Poll F, Lehmann D, Illing S, Ginj M, Jacobs S, Lupp A, Stumm R \& Schulz S 2010 Pasireotide and octreotide stimulate distinct patterns of sst2A somatostatin receptor phosphorylation. Molecular Endocrinology $\mathbf{2 4}$ 436-446. (doi:10.1210/me.2009-0315)

Presky DH \& Schonbrunn A 1988 Iodination of [Tyr11]somatostatin yields a super high affinity ligand for somatostatin receptors in GH4C1 pituitary cells. Molecular Pharmacology 34 651-658.

Puente E, Saint-Laurent N, Torrisani J, Furet C, Schally AV, Vaysse N, Buscail L \& Susini C 2001 Transcriptional activation of mouse sst2 somatostatin receptor promoter by transforming growth factor-beta, Involvement of Smad4. Journal of Biological Chemistry 276 1346113468. (doi:10.1074/jbc.M010981200)

Quintela M, Senaris R, Heiman ML, Casanueva FF \& Dieguez C 1997a Leptin inhibits in vitro hypothalamic somatostatin secretion and somatostatin mRNA levels. Endocrinology 138 5641-5644.

Quintela M, Senaris RM \& Dieguez C $1997 b$ Transforming growth factorbetas inhibit somatostatin messenger ribonucleic acid levels and somatostatin secretion in hypothalamic cells in culture. Endocrinology 138 4401-4409. (doi:10.1210/endo.138.10.5467)

Ramirez JL, Gracia-Navarro F, Garcia-Navarro S, Torronteras R, Malagon MM \& Castano JP 2002 Somatostatin stimulates GH secretion in two porcine somatotrope subpopulations through a cAMPdependent pathway. Endocrinology 143 889-897. (doi:10.1210/endo. 143.3.8685)

Reichlin S 1983 Somatostatin. New England Journal of Medicine 309 1495-1501. (doi:10.1056/NEJM198312153092406)

Reisine T \& Axelrod J 1983 Prolonged somatostatin pretreatment desensitizes somatostatin's inhibition of receptor-mediated release of adrenocorticotropin hormone and sensitizes adenylate cyclase. Endocrinology 113 811-813. (doi:10.1210/endo-113-2-811)

Ren SG, Taylor J, Dong J, Yu R, Culler MD \& Melmed S 2003 Functional association of somatostatin receptor subtypes 2 and 5 in inhibiting human growth hormone secretion. Journal of Clinical Endocrinology and Metabolism 88 4239-4245. (doi:10.1210/jc.2003-030303)

Resmini E, Dadati P, Ravetti JL, Zona G, Spaziante R, Saveanu A, Jaquet P, Culler MD, Bianchi F, Rebora A et al. 2007 Rapid pituitary tumor shrinkage with dissociation between antiproliferative and antisecretory effects of a long-acting octreotide in an acromegalic patient. Journal of Clinical Endocrinology and Metabolism 92 1592-1599. (doi:10.1210/ jc.2006-2084)

Richardson SB, Hollander CS, D'Eletto R, Greenleaf PW \& Thaw C 1980 Acetylcholine inhibits the release of somatostatin from rat hypothalamus in vitro. Endocrinology 107 122-129. (doi:10.1210/ endo-107-1-122)

Richardson SB, Hollander CS, Prasad JA \& Hirooka Y 1981 Somatostatin release from rat hypothalamus in vitro: effects of melatonin and serotonin. Endocrinology 109 602-606. (doi:10.1210/endo-109-2-602)

Richardson S, Twente S \& Audhya T 1988 GHRF causes biphasic stimulation of SRIF secretion from rat hypothalamic cells. American Journal of Physiology 255 E829-E832.

Richardson SB \& Twente S 1990 Inhibition of hypothalamic somatostatin release by beta-adrenergic antagonists. Endocrinology 126 1043-1046. (doi:10.1210/endo-126-2-1043)
Roosterman D, Kempkes C, Cottrell GS, Padilla BE, Bunnett NW, Turck CW \& Steinhoff M 2008 Endothelin-converting enzyme-1 degrades internalized somatostatin-14. Endocrinology 149 2200-2207. (doi:10.1210/en.2007-1628)

Samuels MH, Henry P \& Ridgway EC 1992 Effects of dopamine and somatostatin on pulsatile pituitary glycoprotein secretion. Journal of Clinical Endocrinology and Metabolism 74 217-222. (doi:10.1210/jcem. 74.1.1345783)

Sarret P, Nouel D, Dal Farra C, Vincent JP, Beaudet A \& Mazella J 1999 Receptor-mediated internalization is critical for the inhibition of the expression of growth hormone by somatostatin in the pituitary cell line AtT-20. Journal of Biological Chemistry 274 19294-19300. (doi:10.1074/ jbc.274.27.19294)

Sassolas G, Khalfallah Y, Chayvialle JA, Cohen R, Merabet S, Casez JP, Calvet P \& Cabrera P 1989 Effects of the somatostatin analog BIM 23014 on the secretion of growth hormone, thyrotropin, and digestive peptides in normal men. Journal of Clinical Endocrinology and Metabolism 68 239-246. (doi:10.1210/jcem-68-2-239)

Scarborough DE, Lee SL, Dinarello CA \& Reichlin S 1989 Interleukin-1 beta stimulates somatostatin biosynthesis in primary cultures of fetal rat brain. Endocrinology 124 549-551. (doi:10.1210/endo-124-1-549)

Schussler N, Farnoud R, Rauch C, Roche M, Berthet M, Thomas F, Peillon F \& Bayet MC 1994 Effect of the slow-release formulation of somatuline (BIM 23014) on estrogen-induced hyperprolactinemia and lactotroph hyperplasia in the female rat. Neuropeptides 26 399-404. (doi:10.1016/ 0143-4179(94)90025-6)

Seifert R \& Wenzel-Seifert K 2002 Constitutive activity of G-proteincoupled receptors: cause of disease and common property of wild-type receptors. Naunyn-Schmiedeberg's Archives of Pharmacology 366 381-416. (doi:10.1007/s00210-002-0588-0)

Senaris RM, Lago F, Lewis MD, Dominguez F, Scanlon MF \& Dieguez C 1992 Differential effects of in vivo estrogen administration on hypothalamic growth hormone releasing hormone and somatostatin gene expression. Neuroscience Letters 141 123-126. (doi:10.1016/03043940(92)90349-C)

Sheppard MC, Kronheim S \& Pimstone BL 1978 Stimulation by growth hormone of somatostatin release from the rat hypothalamus in vitro. Clinical Endocrinology 9 583-586. (doi:10.1111/j.1365-2265.1978. tb01518.x)

Sheppard MC, Kronheim S \& Pimstone BL 1979 Effect of substance P, neurotensin and the enkephalins on somatostatin release from the rat hypothalamus in vitro. Journal of Neurochemistry 32 647-649. (doi:10. 1111/j.1471-4159.1979.tb00400.x)

Shimada O, Tosaka-Shimada H \& Ishikawa H 1990 Morphological effects of somatostatin on rat somatotrophs previously activated by growth hormone-releasing factor. Cell and Tissue Research 261 219-229. (doi:10.1007/BF00318663)

Shimatsu A, Kato Y, Matsushita N, Katakami H, Yanaihara N \& Imura H 1982 Effects of glucagon, Neurotensin, and vasoactive intestinal polypeptide on somatostatin release from perifused rat hypothalamus. Endocrinology 110 2113-2117. (doi:10.1210/endo-110-6-2113)

Shimon I, Yan X, Taylor JE, Weiss MH, Culler MD \& Melmed S $1997 a$ Somatostatin receptor (SSTR) subtype-selective analogues differentially suppress in vitro growth hormone and prolactin in human pituitary adenomas, Novel potential therapy for functional pituitary tumors. Journal of Clinical Investigation 100 2386-2392. (doi:10.1172/JCI119779)

Shimon I, Taylor JE, Dong JZ, Bitonte RA, Kim S, Morgan B, Coy DH, Culler MD \& Melmed S 1997b Somatostatin receptor subtype specificity in human fetal pituitary cultures, Differential role of SSTR2 and SSTR5 for growth hormone, thyroid-stimulating hormone, and prolactin regulation. Journal of Clinical Investigation 99 789-798. (doi:10.1172/ JCI119225)

Simard J, Labrie F \& Gossard F 1986 Regulation of growth hormone mRNA and pro-opiomelanocortin mRNA levels by cyclic AMP in rat anterior pituitary cells in culture. DNA 5 263-270. (doi:10.1089/dna.1986.5.263) 
Simonian SX, Murray HE, Gillies GE \& Herbison AE 1998 Estrogendependent ontogeny of sex differences in somatostatin neurons of the hypothalamic periventricular nucleus. Endocrinology 139 1420-1428. (doi:10.1210/endo.139.3.5814)

Soya H \& Suzuki M 1990 A possible role of hypothalamic somatostatin in the maintenance of rat pituitary responsiveness to growth hormone-releasing factor. Endocrinology 126 285-291. (doi:10.1210/endo-126-1-285)

Spada A, Reza-Elahi F, Lania A, Bassetti M \& Atti E 1990 Inhibition of basal and corticotropin-releasing hormone-stimulated adenylate cyclase activity and cytosolic $\mathrm{Ca}^{2+}$ levels by somatostatin in human corticotropin-secreting pituitary adenomas. Journal of Clinical Endocrinology and Metabolism 70 1262-1268. (doi:10.1210/jcem-70$5-1262)$

Spier AD \& de Lecea L 2000 Cortistatin: a member of the somatostatin neuropeptide family with distinct physiological functions. Brain Research. Brain Research Reviews 33 228-241. (doi:10.1016/S01650173(00)00031-X)

Spoudeas HA, Matthews DR, Brook CG \& Hindmarsh PC 1992 The effect of changing somatostatin tone on the pituitary growth hormone and thyroid-stimulating hormone responses to their respective releasing factor stimuli. Journal of Clinical Endocrinology and Metabolism $\mathbf{7 5}$ 453-458. (doi:10.1210/jcem.75.2.1353504)

Stafford PJ, Kopelman PG, Davidson K, McLoughlin L, White A, Rees LH, Besser GM, Coy DH \& Grossman A 1989 The pituitary-adrenal response to CRF-41 is unaltered by intravenous somatostatin in normal subjects. Clinical Endocrinology 30 661-666. (doi:10.1111/j.1365-2265.1989. tb00272.x)

Starcevic V, Milosevic V, Brkic B \& Severs WB 2002 Somatostatin affects morphology and secretion of pituitary luteinizing hormone (LH) cells in male rats. Life Sciences 70 3019-3027. (doi:10.1016/S0024-3205 (02)01551-5)

Strowski MZ, Kohler M, Chen HY, Trumbauer ME, Li Z, Szalkowski D, Gopal-Truter S, Fisher JK, Schaeffer JM, Blake AD et al. 2003 Somatostatin receptor subtype 5 regulates insulin secretion and glucose homeostasis. Molecular Endocrinology 17 93-106. (doi:10.1210/me. 2001-0035)

Sugihara H, Minami S, Okada K, Kamegai J, Hasegawa O \& Wakabayashi I 1993 Somatostatin reduces transcription of the growth hormone gene in rats. Endocrinology 132 1225-1229. (doi:10.1210/endo.132.3. 7679974)

Taboada GF, Luque RM, Neto LV, Machado Ede O, Sbaffi BC, Domingues RC, Marcondes JB, Chimelli LM, Fontes R, Niemeyer P et al. 2008 Quantitative analysis of somatostatin receptor subtypes (1-5) gene expression levels in somatotropinomas and correlation to in vivo hormonal and tumor volume responses to treatment with octreotide LAR. European Journal of Endocrinology 158 295-303. (doi:10.1530/ EJE-07-0562)

Takano K, Yasufuku-Takano J, Kozasa T, Nakajima S \& Nakajima Y 1997 Different $G$ proteins mediate somatostatin-induced inward rectifier $\mathrm{K}^{+}$ currents in murine brain and endocrine cells. Journal of Physiology 502 559-567. (doi:10.1111/j.1469-7793.1997.559bj.x)

Tallent M \& Reisine T 1992 Gi $\alpha 1$ selectively couples somatostatin receptors to adenylyl cyclase in pituitary-derived AtT-20 cells. Molecular Pharmacology 41 452-455.

Tanner JW, Davis SK, McArthur NH, French JT \& Welsh TH Jr 1990 Modulation of growth hormone (GH) secretion and GH mRNA levels by GH-releasing factor, somatostatin and secretagogues in cultured bovine adenohypophysial cells. Journal of Endocrinology 125 109-115. (doi:10.1677/joe.0.1250109)

Tentler JJ, Hadcock JR \& Gutierrez-Hartmann A 1997 Somatostatin acts by inhibiting the cyclic $3^{\prime}, 5^{\prime}$-adenosine monophosphate (cAMP)/protein kinase A pathway, cAMP response element-binding protein (CREB) phosphorylation, and CREB transcription potency. Molecular Endocrinology 11 859-866. (doi:10.1210/mend.11.7.9943)

Theodoropoulou M, Zhang J, Laupheimer S, Paez-Pereda M, Erneux C, Florio T, Pagotto U \& Stalla GK 2006 Octreotide, a somatostatin analogue, mediates its antiproliferative action in pituitary tumor cells by altering phosphatidylinositol 3-kinase signaling and inducing Zac1 expression. Cancer Research 66 1576-1582. (doi:10.1158/0008-5472. CAN-05-1189)

Theodoropoulou M, Tichomirowa MA, Sievers C, Yassouridis A, Arzberger T, Hougrand O, Deprez M, Daly AF, Petrossians P, Pagotto U et al. 2009 Tumor ZAC1 expression is associated with the response to somatostatin analog therapy in patients with acromegaly. International Journal of Cancer 125 2122-2126. (doi:10.1002/ijc.24602)

Tsaneva-Atanasova K, Sherman A, van Goor F \& Stojilkovic SS 2007 Mechanism of spontaneous and receptor-controlled electrical activity in pituitary somatotrophs: experiments and theory. Journal of Neurophysiology 98 131-144. (doi:10.1152/jn.00872.2006)

Tsukamoto N, Nagaya T, Kuwayama A, Takano K, Shizume K, Sugita K \& Seo H 1994 Octreotide treatment results in the inhibition of GH gene expression in the adenoma of the patients with acromegaly. Endocrine Journal 41 437-444. (doi:10.1507/endocrj.41.437)

Tsukamoto N, Otsuka F, Miyoshi T, Yamanaka R, Inagaki K, Yamashita M, Otani H, Takeda M, Suzuki J, Ogura T et al. 2010 Effects of bone morphogenetic protein (BMP) on adrenocorticotropin production by pituitary corticotrope cells: involvement of up-regulation of BMP receptor signaling by somatostatin analogs. Endocrinology $\mathbf{1 5 1}$ 1129-1141. (doi:10.1210/en.2009-1102)

Tsukamoto N, Otsuka F, Miyoshi T, Inagaki K, Nakamura E, Suzuki J, Ogura T, Iwasaki Y \& Makino H 2011 Activities of bone morphogenetic proteins in prolactin regulation by somatostatin analogs in rat pituitary GH3 cells. Molecular and Cellular Endocrinology 332 163-169. (doi:10.1016/j.mce.2010.10.008)

Tyrrell JB, Lorenzi M, Gerich JE \& Forsham PH 1975 Inhibition by somatostatin of ACTH secretion in Nelson's syndrome. Journal of Clinical Endocrinology and Metabolism 40 1125-1127. (doi:10.1210/ jcem-40-6-1125)

Vesely DL 1980 The interrelationship of somatostatin and guanylate cyclase activity. Molecular and Cellular Biochemistry 32 131-134. (doi:10.1007/BF00227439)

Visser-Wisselaar HA, Van Uffelen CJ, Van Koetsveld PM, Lichtenauer-Kaligis EG, Waaijers AM, Uitterlinden P, Mooy DM, Lamberts SW \& Hofland LJ 1997 17- $\beta$-Estradiol-dependent regulation of somatostatin receptor subtype expression in the $7315 \mathrm{~b}$ prolactin secreting rat pituitary tumor in vitro and in vivo. Endocrinology 138 1180-1189. (doi:10.1210/endo.138.3.5016)

Volpi R, Chiodera P, Capretti L, Caiazza A, Caffarri G, Magotti MG, Boni S \& Coiro V 1996 Inhibition by somatostatin of the growth hormone, but not corticotropin response to angiotensin II in normal men. Hormone Research 45 269-272. (doi:10.1159/000184804)

War SA \& Kumar U 2012 Coexpression of human somatostatin receptor-2 (SSTR2) and SSTR3 modulates antiproliferative signaling and apoptosis. Journal of Molecular Signaling 7 5. (doi:10.1186/1750-2187-7-5)

Werle M \& Bernkop-Schnurch A 2006 Strategies to improve plasma half life time of peptide and protein drugs. Amino Acids 30 351-367. (doi:10.1007/s00726-005-0289-3)

Werner H, Koch Y, Baldino F Jr \& Gozes I 1988 Steroid regulation of somatostatin mRNA in the rat hypothalamus. Journal of Biological Chemistry 263 7666-7671.

White RE, Schonbrunn A \& Armstrong DL 1991 Somatostatin stimulates $\mathrm{Ca}(2+)$-activated $\mathrm{K}^{+}$channels through protein dephosphorylation. Nature 351 570-573. (doi:10.1038/351570a0)

White RE, Lee AB, Shcherbatko AD, Lincoln TM, Schonbrunn A \& Armstrong DL 1993 Potassium channel stimulation by natriuretic peptides through cGMP-dependent dephosphorylation. Nature $\mathbf{3 6 1}$ 263-266. (doi: 10.1038/361263a0)

Xu Y, Berelowitz M \& Bruno JF 1995 Dexamethasone regulates somatostatin receptor subtype messenger ribonucleic acid expression in rat pituitary GH4C1 cells. Endocrinology 136 5070-5075. (doi:10.1210/ endo.136.11.7588243) http://jme.endocrinology-journals.org DOI: 10.1530/JME-14-0034
() 2014 Society for Endocrinology Printed in Great Britain 
Yan M, Jones ME, Hernandez M, Liu D, Simpson ER \& Chen C 2004 Functional modification of pituitary somatotropes in the aromatase knockout mouse and the effect of estrogen replacement. Endocrinology 145 604-612. (doi:10.1210/en.2003-0646)

Yang SK \& Chen C 2007 Involvement of somatostatin receptor subtypes in membrane ion channel modification by somatostatin in pituitary somatotropes. Clinical and Experimental Pharmacology \& Physiology 34 1221-1227. (doi:10.1111/j.1440-1681.2007.04806.x)

Yang SK, Parkington HC, Blake AD, Keating DJ \& Chen C 2005 Somatostatin increases voltage-gated $\mathrm{K}^{+}$currents in $\mathrm{GH} 3$ cells through activation of multiple somatostatin receptors. Endocrinology 146 4975-4984. (doi:10.1210/en.2005-0696)

Yang SK, Parkington HC, Epelbaum J, Keating DJ \& Chen C 2007 Somatostatin decreases voltage-gated $\mathrm{Ca}^{2+}$ currents in $\mathrm{GH} 3$ cells through activation of somatostatin receptor 2. American Journal of Physiology. Endocrinology and Metabolism 292 E1863-E1870. (doi:10.1152/ajpendo.00047.2007)

Yu WH, Kimura M \& McCann SM 1997 Effect of somatostatin on the release of gonadotropins in male rats. Proceedings of the Society for Experimental Biology and Medicine 214 83-86. (doi:10.3181/00379727214-44073)

Zatelli MC, Piccin D, Tagliati F, Ambrosio MR, Margutti A, Padovani R, Scanarini M, Culler MD \& degli Uberti EC 2003 Somatostatin receptor subtype 1 selective activation in human growth hormone (GH)- and prolactin (PRL)-secreting pituitary adenomas: effects on cell viability, GH, and PRL secretion. Journal of Clinical Endocrinology and Metabolism 88 2797-2802. (doi:10.1210/jc.2002-021825)
Zatelli MC, Piccin D, Vignali C, Tagliati F, Ambrosio MR, Bondanelli M, Cimino V, Bianchi A, Schmid HA, Scanarini M et al. 2007 Pasireotide, a multiple somatostatin receptor subtypes ligand, reduces cell viability in non-functioning pituitary adenomas by inhibiting vascular endothelial growth factor secretion. Endocrine-Related Cancer 14 91-102. (doi:10.1677/ERC-06-0026)

Zeyda T \& Hochgeschwender U 2008 Null mutant mouse models of somatostatin and cortistatin, and their receptors. Molecular and Cellular Endocrinology 286 18-25. (doi:10.1016/j.mce.2007.11.029)

Zeyda T, Diehl N, Paylor R, Brennan MB \& Hochgeschwender U 2001 Impairment in motor learning of somatostatin null mutant mice. Brain Research 906 107-114. (doi:10.1016/S0006-8993(01) 02563-X)

Zhang L, Li W, Hong X \& Lin H 2009 Regulation of preprosomatostatin 1 (PSS1) gene expression by 17beta-estradiol and identification of the PSS1 promoter region in orange-spotted grouper (Epinephelus coioides). Molecular and Cellular Endocrinology 311 87-93. (doi:10.1016/ j.mce.2009.06.008)

Zheng H, Bailey A, Jiang MH, Honda K, Chen HY, Trumbauer ME, Van der Ploeg LH, Schaeffer JM, Leng G \& Smith RG 1997 Somatostatin receptor subtype 2 knockout mice are refractory to growth hormone-negative feedback on arcuate neurons. Molecular Endocrinology 11 1709-1717. (doi:10.1210/mend.11.11.0016)

Zorrilla R, Simard J, Rheaume E, Labrie F \& Pelletier G 1990 Multihormonal control of pre-pro-somatostatin mRNA levels in the periventricular nucleus of the male and female rat hypothalamus. Neuroendocrinology 52 527-536. (doi:10.1159/000125639)

Received in final form 17 April 2014

Accepted 24 April 2014

Accepted Preprint published online 29 April 2014
() 2014 Society for Endocrinology Printed in Great Britain
Published by Bioscientifica Ltd. 